\title{
Jens Esmark's Christiania (Oslo) meteorological observations 1816-1838: the first long-term continuous temperature record from the Norwegian capital homogenized and analysed
}

\author{
Geir Hestmark ${ }^{1}$ and Øyvind Nordli ${ }^{2}$ \\ ${ }^{1}$ Centre for Ecological and Evolutionary Synthesis, CEES, Department of Biosciences, Box 1066 Blindern, \\ University of Oslo, 0316 Oslo, Norway \\ ${ }^{2}$ Norwegian Meteorological Institute (MET Norway), Research and Development Department, Division for Model and \\ Climate Analysis, P.O. Box 43 Blindern, 0313 Oslo, Norway
}

Correspondence to: Geir Hestmark (geir.hestmark@ibv.uio.no)

Received: 1 June 2016 - Published in Clim. Past Discuss.: 20 June 2016

Revised: 17 October 2016 - Accepted: 19 October 2016 - Published: 18 November 2016

\begin{abstract}
In 2010 we rediscovered the complete set of meteorological observation protocols made by Jens Esmark (1762-1839) during his years of residence in the Norwegian capital of Oslo (then Christiania). From 1 January 1816 to 25 January 1839, Esmark at his house in Øvre Voldgate in the morning, early afternoon and late evening recorded air temperature with state-of-the-art thermometers. He also noted air pressure, cloud cover, precipitation and wind directions, and experimented with rain gauges and hygrometers. From 1818 to the end of 1838 he twice a month provided weather tables to the official newspaper Den Norske Rigstidende, and thus acquired a semi-official status as the first Norwegian state meteorologist. This paper evaluates the quality of Esmark's temperature observations and presents new metadata, new homogenization and analysis of monthly means. Three significant shifts in the measurement series were detected, and suitable corrections are proposed. The air temperature in Oslo during this period is shown to exhibit a slow rise from 1816 towards 1825 , followed by a slighter fall again towards 1838 .
\end{abstract}

\section{Introduction}

The current concern with climate change has increased the interest in early meteorological observation series and evaluation of their quality (e.g. Bergström and Moberg, 2002; Auer et al., 2007). In a recent paper we analysed the temperature record for the Norwegian capital made between 1837 and 2012 by the Astronomical Observatory at the University of Oslo and the Norwegian Meteorological Institute (MET Norway) (Nordli et al., 2015). Previous to 1837, long-term observations of the Oslo weather were known to have been made by Jens Esmark (1762-1839), professor of mining sciences at the University of Oslo (then Christiania). A first reanalysis of Esmark's observations was made by meteorologist B. J. Birkeland (Birkeland, 1925). Our rediscovery in 2010 of Esmark's original meteorological observation protocols has provided an opportunity to digitize, homogenize and analyse his data with modern methods.

Esmark is today mostly remembered for his pioneer ascents of many of Norway's highest peaks (Esmark, 1802, 1812; Hestmark, 2009), his discovery of ice ages, and his astronomical explanation of such dramatic climate change as caused by variations in the eccentricity of the orbit of the Earth, a hypothesis now recognized as a precursor of the theories of James Croll and Milutin Milankovich (Esmark, 1824, 1826; Andersen, 1992; Worsley, 2006; Rudwick, 2008; Berger, 2012; Krüger, 2013). In his own lifetime he was primarily known as a skilful mineralogist and geologist. Throughout his life Esmark maintained a passion for meteorological observation with instruments he crafted himself in accordance with the highest contemporary standards. His main inspiration for this activity was his teachers at Copenhagen University, which he attended 1784-1789; first among them was the Astronomer Royal Thomas Bugge (17401815), who in his observatory tower, Rundetårn, in the mid- 
dle of Copenhagen, made daily measurements of the weather (Willaume-Jantzen, 1896). Esmark also befriended Bugge's instrument maker, the Swede Johan(nes) Ahl (1729-1795) (Esmark, 1825; Anonymous, 1839). In addition, Esmark followed the lectures of Christian Gottlieb Kratzenstein (17231795), professor of medicine and experimental physics, a "hands-on" practical man who enjoyed crafting instruments and all sorts of mechanical machines (Kratzenstein, 1791; Snorrason, 1974; Splinter, 2007). From 1789 to 1791 Esmark studied mining sciences at the Norwegian silver town of Kongsberg, and after further studies in Freiberg, Saxony, and Schemnitz in today's Slovakia, in 1798 he moved back to Kongsberg to take up a position as assessor in the central mining administration (Overbergamtet) of the dual kingdom Denmark-Norway. At Kongsberg he also lectured in mineralogy, geology and experimental physics at the Royal Norwegian Mining Seminar, acting as its temporary inspector from 1799, and permanent inspector from 1802 to 1815 . From 1 January 1799 he three times a day recorded observations of the Kongsberg weather - air pressure on mercury barometers (in inches and lines) and air temperature in degrees Réaumur. This was documented in a series of small notebooks running continuously with some lacunae until 16 September 1810, which were rediscovered by the authors in 2010 (Esmark, 1799-1810). When Esmark in 1815 moved to the Norwegian capital Christiania (now Oslo) to become the first professor in the mining sciences at the university, he continued this habit. At least from January 1816 up to and including day before his death on 26 January 1839 he recorded air temperature and barometric pressure three times a day. The complete set of his 23 Christiania observation protocols, long believed lost, was rediscovered in 2010 by the authors, and is now safely deposited in the Norwegian National Archive (Riksarkivet) (Esmark, 1816-1838). They provide a unique and detailed picture of the weather in Oslo in the early 19th century. From January 1818 to December 1838 tables of Esmark's observations were published every fortnight in the official newspaper Den Norske Rigstidende (see Appendix A), and he thus acquired a semi-official position as Norway's first state meteorologist. Based on a number of previously unpublished documents (cited as Document 1, 2 etc., with archival location in the reference list) we present here new metadata for Esmark's meteorological observations from Christiania and homogenize, analyse and evaluate his original temperature data with modern statistical tools to characterize the temperature variations in the Norwegian capital in this period.

\section{Metadata}

\subsection{The location - No. 308, Vestre Rode - Øvre} Vollgate 7

Esmark's observations were made at his home (see Esmark, 1823: De ere tagne i min Bopel), and there is no evidence in- dicating that he changed the location. On 19 August 1815 Esmark was registered as owner of property No. 308 in Vestre Rode (i.e. Western Quarter), one of the four old quarters of Christiania town (Document 1). It was a modest oneand-half-storey house built late in the 18th century with an adjoining garden. Esmark's continued residence at this address until his death is documented in annual censuses and tax protocols (Document 2). Property No. 308 was situated on the north-western side of the street $\emptyset_{\text {vre Vollgate }} \varnothing_{\mathrm{v} r e}$ Woldgaden), laid out literally on what used to be the outermost western rampart (voll) of nearby Akershus Castle and Fortress (Fig. 1). It was a natural rock promontory above a meadow to the west where the poor fishing village Pipervigen would develop later in the 19th century, today the site of Oslo Town Hall. In 1815 Øvre Vollgate constituted the south-western limit of Christiania, a town with only about 15000 citizens (Myhre, 1990). Until 1814 the main administration centre of the dual kingdom was in Copenhagen, but with Christiania in that year acquiring the new parliament and government after the separation of Norway from Denmark, the town expanded rapidly. When street numbers were introduced, Esmark's property was numbered $\emptyset_{v r e}$ Vollgate

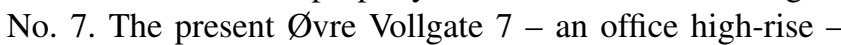
comprises previous numbers $\emptyset_{v}$ re Vollgate 3, 5 and 7.

Esmark's property No. 308 and all neighbouring properties were measured and mapped for the new matriculation of Christiania in the summer of 1830, and thus we have very precise data on his house and the surrounding properties at the relevant time (Document 3 ). The whole property roughly constituted an elongated rectangle, approximately $14 \mathrm{~m} \times 60 \mathrm{~m}$ (Fig. 2). The unit used in these measurements was the "Norwegian alen" (Norsk alen), determined by law in 1824 to be $62.75 \mathrm{~cm}$. It was divided into 2 feet, each divided into 12 inches, each divided into 12 lines. No. 308 was measured to 2026 square alen, of which the house (including a yard) was $7331 / 2$ and the garden $12921 / 2$ square alen (1 square alen $=0.3937 \mathrm{~m}^{2}$ ). Thus, the whole property was ca. $800 \mathrm{~m}^{2}$, and the house (including yard) ca. $290 \mathrm{~m}^{2}$. The house had a 22-alen, 6-inch (ca. $14 \mathrm{~m}$ ) long façade towards the street $\emptyset_{v r e}$ Voldgate, constituting the south-eastern border of the property, with windows, doors, and a gate leading into the backyard (Fig. 3). Øvre Vollgate street runs from SW to $\mathrm{NE}$ at an angle of roughly $32^{\circ} \mathrm{NE}\left(400^{\circ}\right)$. At the back the house surrounded a small yard, with a narrow passage opening out to the garden in the NW. As it would have been hazardous to place the meteorological instruments on the street side of the house, where passers-by could tinker with them, it is almost certain that they were placed in Esmark's backyard, a well-guarded space. When the house was finally demolished in 1938, it was in such a bad condition that the Oslo city health authorities demanded the whole property be sprayed with hydrocyanic acid and that none of the fungusinfected material be used for construction elsewhere (Document 4). 


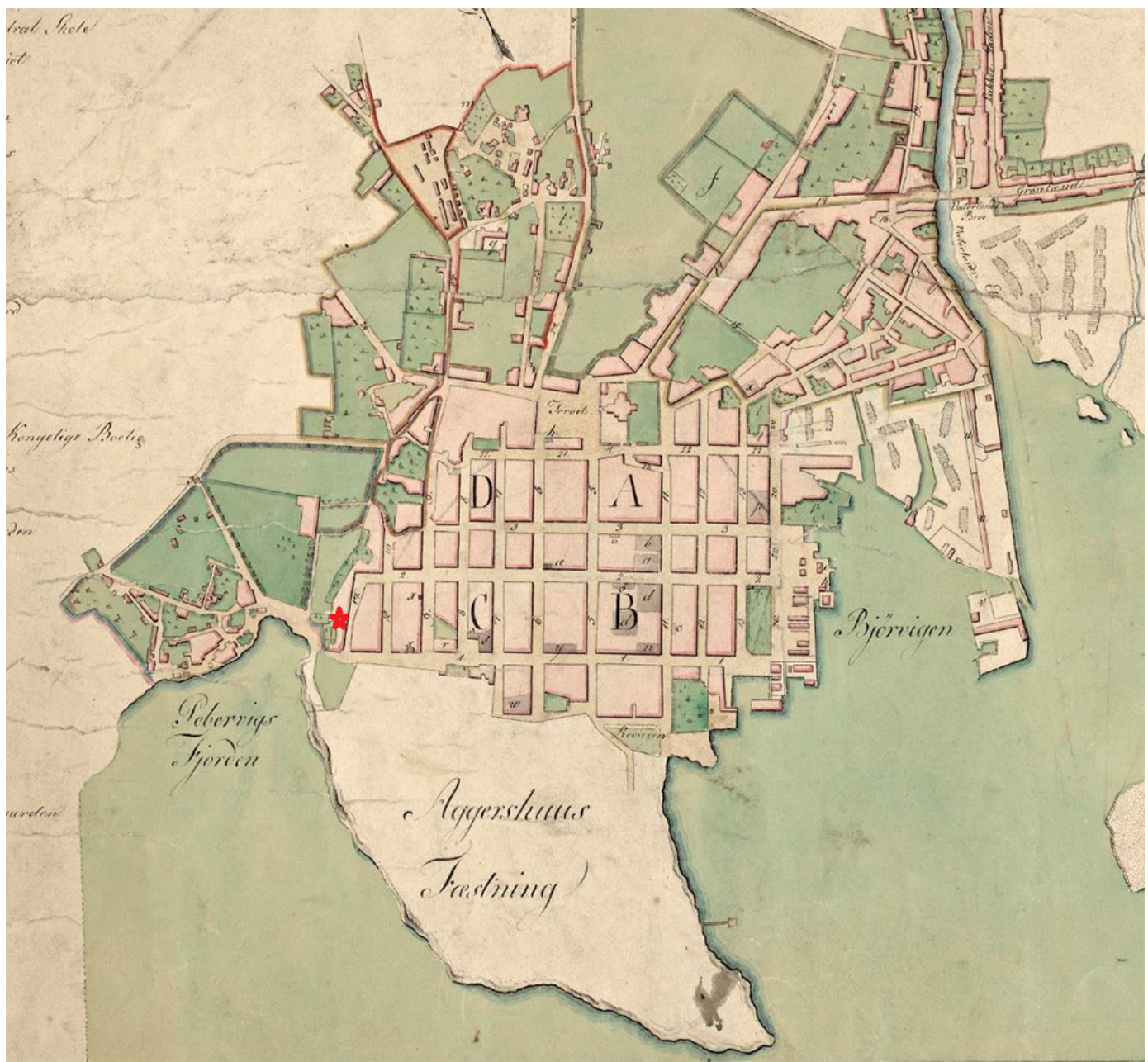

Figure 1. Map of Christiania (now Oslo) 1811 with the location (red star) of Esmark's house in Øvre Vollgate 7 marked.

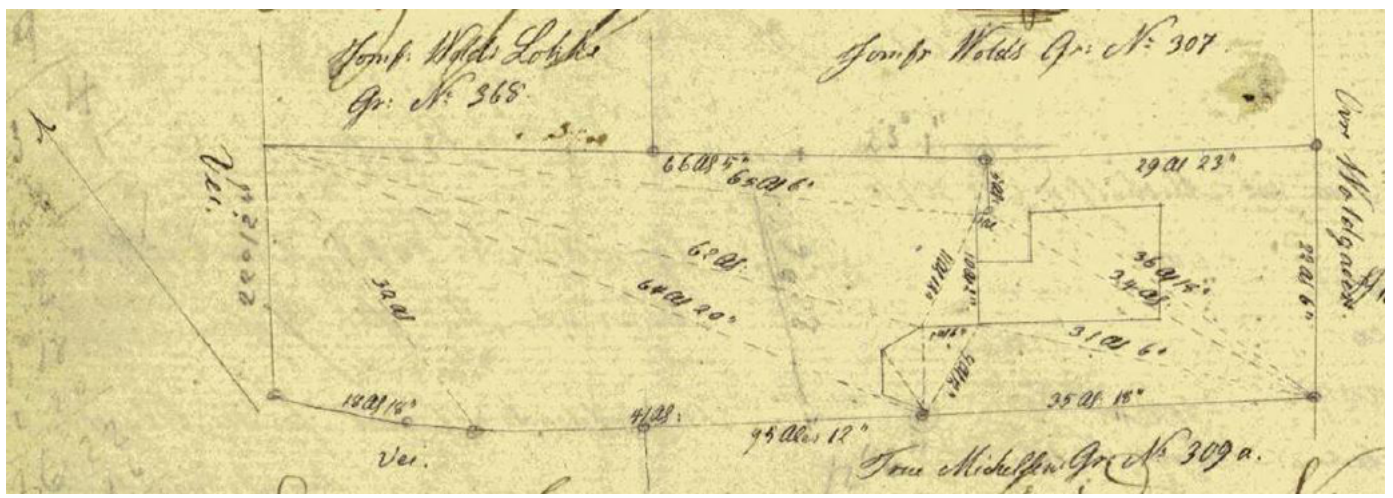

Figure 2. Matriculation and survey 1830 of Esmark's property No. 308, Øvre Voldgate 7, in Oslo Byarkiv (Oslo City Archive). Arrow indicates north. Garden to the left, and house surrounding backyard to the right.

Esmark's garden on the NW side of the house and court yard was a continuous slope, dropping 10 alen $(6.25 \mathrm{~m})$ down along 66 alen length towards Pipervika. Here it was most probably limited by a fence towards the street Præste Gade, which later changed name to today's Rosenkrantz' street. In 1841, a couple of years after Esmark's death, most of this garden was sectioned out and sold to form the new property Rosenkrantz' gate 26. In Esmark's time, however, 


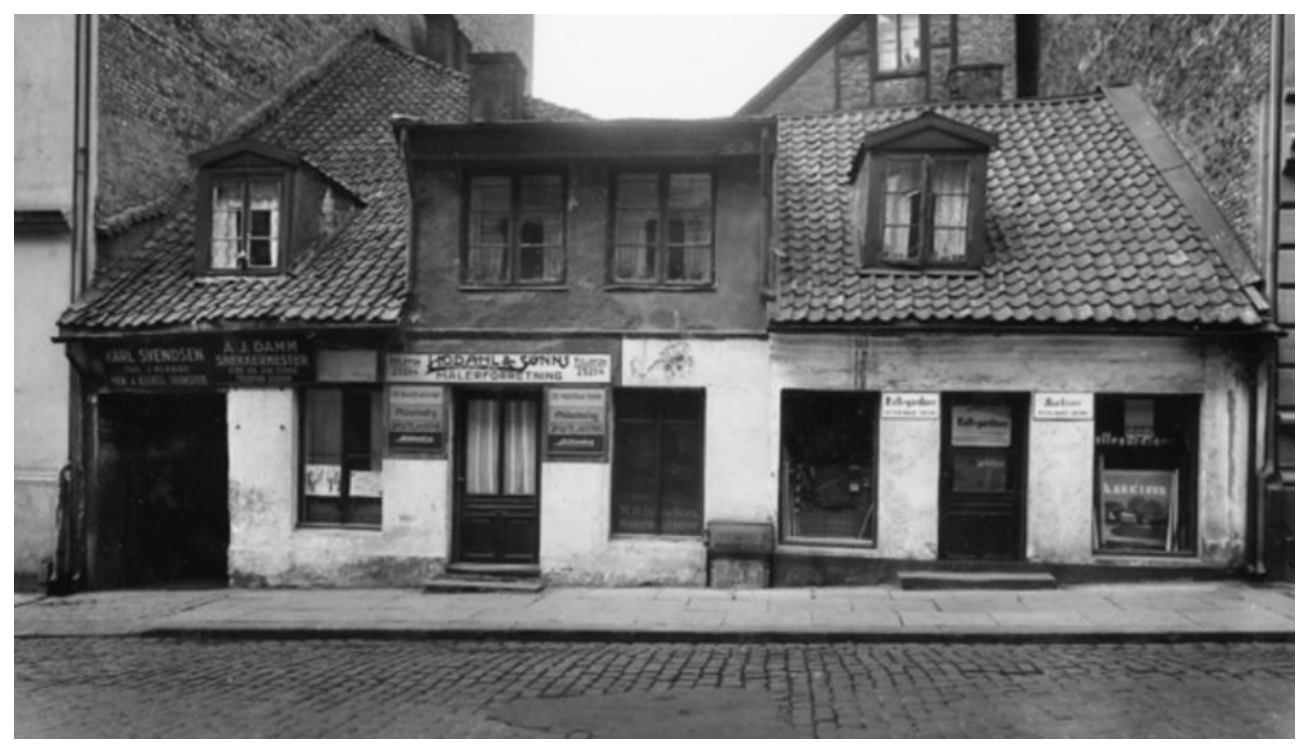

Figure 3. Street view of Esmark's house in Øvre Voldgate 7. Photograph from around 1900. Oslo Bymuseum, No. OB.F00897. The high buildings on each side were built in late 19th century.

the promontory remained an open garden space. His neighbours on both sides (No. 307 and No. 309) had the same arrangement of house and garden, with facades to Øvre Vollgate and gardens sloping down on the back to Præstegaden (Document 5). To the north of the lowermost part of Esmark's property was an open space called Jomfru Wold's Løkke (No. 368). South of this lower part of the garden was the street Pipervigbakken, leading down from Rådhusgaten street passing by the outer ramparts of Akershus Castle and Fortress. The sea with Pipervika Bay (Piperviks Bugten) was less than $200 \mathrm{~m}$ south of Esmark's garden. His garden was not an entirely constant environment. In 1823, for instance, he received several fruit trees from a Danish friend which he planted in the garden (Document 6).

It was a modest residence for a professor, situated in a comparatively poor part of town, with mainly craftsmen, tradesmen and artisans in the neighbourhood (Myhre, 1990: p. 40). Here Esmark, a widower since 1811, moved in with his three sons Hans Morten, Petter and Lauritz, as well as a maid and a manservant (Document 2). His daughter Elise resided with her grandparents in Copenhagen, but later returned to Norway to take up residence in No. 308.

\subsection{The observers}

The great majority of the Christiania observations were made and noted down by Esmark himself, who has easily recognizable handwriting. His position as a professor in the mining sciences did, however, sometimes cause him to leave town on short or long field excursions, some lasting several months. He was away from Christiania on long voyages in 1818 (Hallingdal), 1819 (Kristiansand), 1822 (Bergen), 1823 (round-trip, Southern Norway), 1826 (Setesdalen),
1827 (Trondhjem) and 1829 (Copenhagen). In his absence his sons seem to have been instructed to continue daily observations, and there are extremely few missing data points. The oldest son, Hans Morten Thrane Esmark (b. 1801), in 1825 became a chaplain in Brevig and moved from Christiania; Axel Petter (b. 1804) became a sailor and was often away from home; and Lauritz Martin (b. 1806), later a professor of zoology at the Christiania University, and daughter Elise Cathrine (b. 1800) remained at home until Esmark's death. The sons evidently did not fully share their father's passion, and although instrument readings were meticulously maintained, the qualitative notes on weather are often restricted to a single word in Esmark's absence. A claim (Birkeland, 1925: p. 5) that the botanist Martin Flor performed the observations in Esmark's absence has not been substantiated.

\subsection{The hours of day}

Esmark's Christiania observation protocols do not indicate the precise hours when the observations were made. The columns are given as morning, noon (really afternoon) and evening (Morgen, Middag, Aften). A note on the first published table in Den Norske Rigstidende on 24 January 1818 also says Morgen, Middag og Aften without further specification (Fig. 5). In a summary table of 15 years (1818-1832) published in 1833, Esmark is more explicit: "The barometer observations have been made daily in the morning, afternoon and evening; in later years at 8.30 a.m., at 3.30 p.m. and at 9.30 p.m.; thermometer observations at the same times in the afternoon and evening and in the morning with the help of the night thermometer. From this the middle height is taken." (Barometerobservationerne ere dagligen gjorte om Morgenen, Eftermiddagen og Aftenen; i de senere Aar Kl. 8 


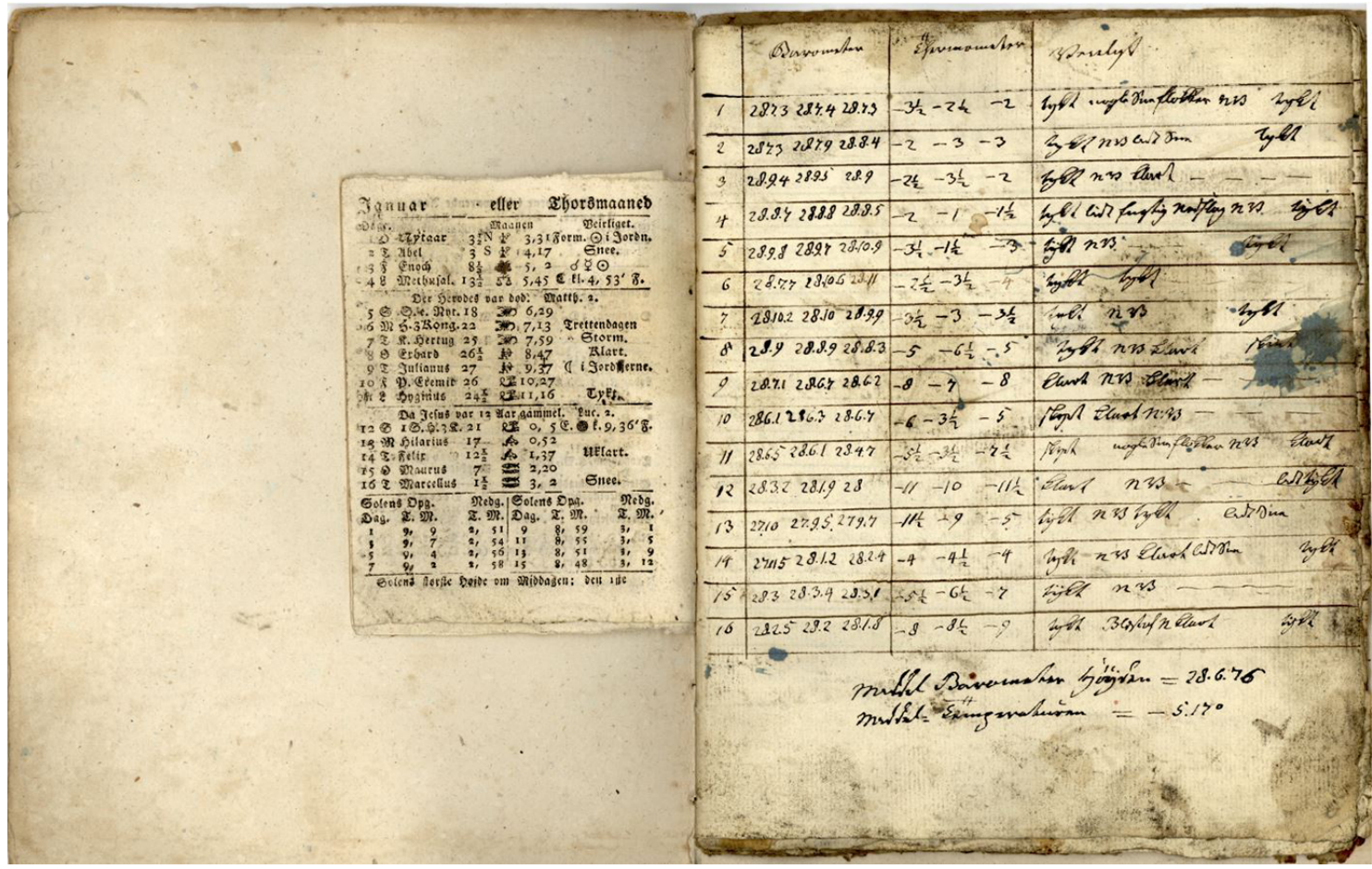

Figure 4. The January page from Esmark's meteorological observation protocol from 1823, the year he discovered ice ages. Esmark 18161838, protocol 1823.

1/2 Morgen, Kl. 3 1/2 Eftermiddag og Kl. 9 1/2 Aften; Thermometerobservationerne paa samme Tider om Eftermiddagen og Aftenen og om Morgenen ved Hjalp af Natthermometret. Heraf er taget Middelhфiden.) (Esmark, 1833: p. 235). The hour 3.30 p.m. probably coincided with Esmark's return to his house from the lectures at the university, just a few blocks away. He regularly lectured from 2.00 to 3.00 p.m. The phrasing "in later years" suggests that the hours had not been constant throughout the whole series, and we address this problem in the analysis.

\subsection{The instruments and their position}

In a note to his first table presented in the journal Den Norske Rigstidende, on 24 January 1818, Esmark provides a few details of his measurements: "The observations are made 34 Rhinelandic feet [i.e. $10.68 \mathrm{~m}$ ] above the sea, and are the middle value of observations made morning, noon and evening. The barometer heights are corrected as they would have been if the barometer was subject to a temperature of $0^{\circ}$. The thermometer hangs freely facing north." (Observationerne ere anstillede 34 Rhinlandske Fod over Havet, og ere Middeltallet af Observationer, anstillede Morgen, Middag og Aften. Barometerhøiderne ere corrigerede saaledes, som de skulle vare, dersom Barometret havde varet udsat for $0^{\circ}$ Temperatur. Thermometret hanger frit imod Nord.) (Fig. 5). Esmark also notes: "The barometer height is reduced to $0{ }^{\circ} \mathrm{R}$. If one wants it reduced to sea level, one must add a line or
$1 / 12$ of an inch to its height, so that the barometer height at sea level becomes 28.1,20 in French measure." (Barometerhøiden er reduceret til $0^{\circ} \mathrm{R}$. Vil Man have den reduceret til Havets Overflade, maa Man til den anforte Hoide lagge en Linie eller 1/12 Deel af en Tomme, saa at Barometerh $\phi i-$ den ved Havets Overflade bliver 28.1,20 i Fransk Maal.) (Esmark, 1833: p. 235).

\subsubsection{Thermometers}

Esmark all his life used the Réaumur scale, R. The precision of his Réaumur thermometer was half of a degree. On a table of averages for the years 1816-1822 Esmark notes: "The thermometer observations are made in shadow in free air with a Réaumur thermometer, whose boiling point is determined at 28 inches 2 lines (French measure) barometric height." (Thermometerobservationerne ere gjorte i Skyggen $i$ fri Luft med et Reaumurs Thermometer, hvis Kogepunkt er bestemt ved 28 Tommers 2 Liniers (fransk Maal) Barometerhöide.) (Esmark, 1823). In Esmark's observation protocol for the year 1816, some instrumental corrections are given for what is claimed to be Esmark's thermometer. They are not written by Esmark himself; most probably they are notes written by Birkeland, who says he has the corrections from Hansteen, but it is not certain that they belong to the thermometer used by Esmark. The corrections are listed in Appendix B but have not been used in the present paper. 


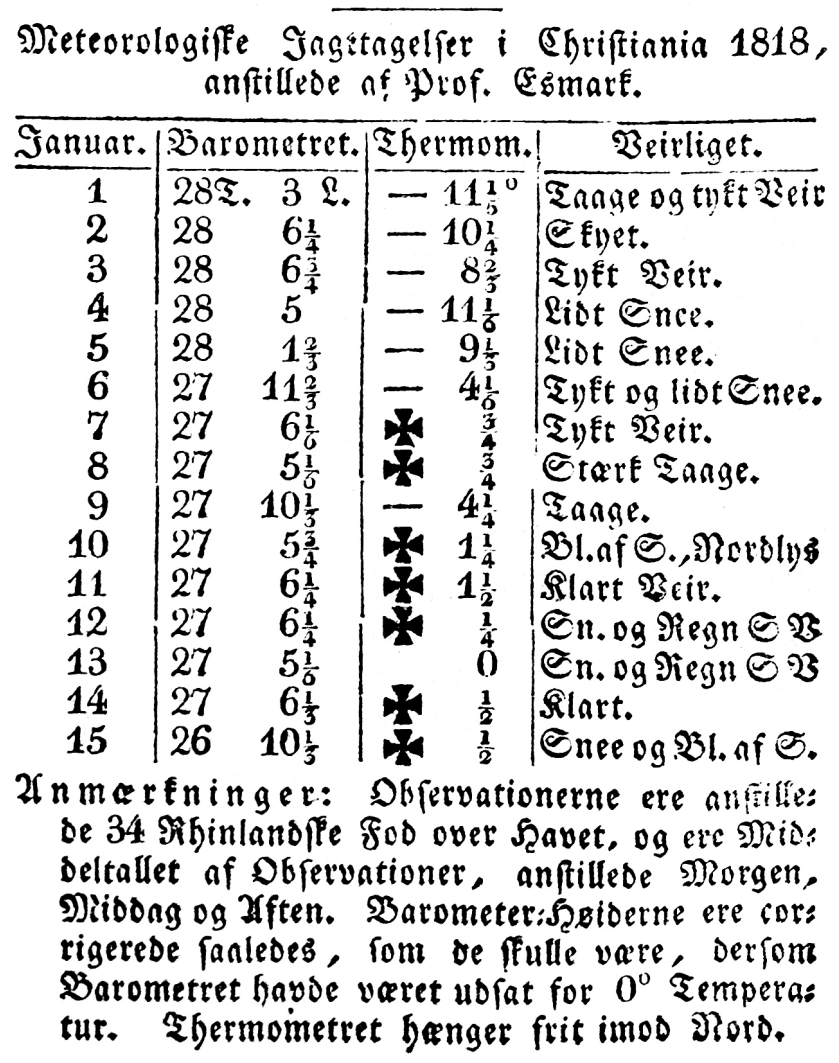

Figure 5. Esmark's first published Christiania weather table, from Den Norske Rigstidende, 24 January 1818. Maltese crosses are intended as plus signs.

\subsubsection{Barometer}

Of the barometer used, Esmark (1833: p. 235) states: "The barometer is a simple barometer, the tube of which is $21 / 2$ lines in diameter and whose capsule is 40 lines in diameter, and calibrated after a siphon barometer." (Barometret er et simpelt Barometer, hvis Rør er 2 1/2 Linie i Diameter og hvis Capsel er 40 Linier i Diameter, samt justeret efter et Havertbarometer.)

\subsection{The protocols and data recorded}

Esmark's Christiania protocols are handmade, folded sheets of white paper cut up and sewn in with a thin grey cardboard cover; there is one protocol for each year, with 23 protocols in all (Esmark, 1816-1838). Esmark interfoliated the official printed Almanach for Christiania. This had, for each month, 16 days on each page, and thus Esmark wrote down his data for 15 or 16 days on the first page of a month and the remaining days from 17 to $28,29,30$ or 31 on the next page (Fig. 4). The protocols start on 1 January 1816 and end 31 December 1838, only 26 days before his death; altogether, there are 8401 days of continuous measurements. There are only a few small lacunae. Photographs of all the protocols are available at MET Norway (Klimadata samba server, HistKlim scanned documents), and digitized values, converted from degrees Réaumur to degrees Celcius, can be downloaded from MET Norway's home page: http://www.met.no. Esmark and his sons continued observations in January 1839 until the day before his death, on 26 January, but these observations are only known through the newspaper Morgenbladet, which had published Esmark's daily measurements since 1834.

Three times a day, Esmark recorded temperature to a half degree and air pressure in inches and lines (Fig. 4). In the right-hand margin he noted the weather (Veirliget) with qualitative terms (see also Esmark, 1833). He used a fairly limited number of categories:

- Precipitation: lidt Regn (a little rain), Fiin Regn (drizzle), Regn (rain), Regn Bygger/B̈̈gger (showers), Regn af og til (rain now and then), megen Regn (much rain), Sne (snow), Sne Flokker (snowflakes), and Sne Bygger (snow showers).

- Cloud cover: Klart (clear), enkelte Skyer (a few clouds), tynde Skyer (thin clouds), skyet (cloudy), skyer i Horizonten (clouds on the horizon), disig (haze), and Taage (fog). The most common category was tykt (thick), which means a grey day with haze, often with precipitation.

- Wind: wind direction was usually recorded only once a day, in the afternoon, with categories $\mathrm{N}, \mathrm{S}, \mathrm{V}$ and $\mathrm{O}$, and combinations, e.g. N. O. (nord ost, north-easterly).

- Other: Torden (thunder), Nordlys (northern lights), Flekker i Solen (sunspots, one or two circles around the sun), and Høyt vand (high sea level).

In June 1818 Esmark introduced a new parameter, precipitation, measured with a rain gauge, and in the June summary, he announced: "In this month there has, according to the rain gauge, fallen rain to a height which, if it had been standing, had constituted a height of 1 inch and 9 and $7 / 12$ lines. The rain gauge is situated 15 feet above sea level." The low altitude of the rain gauge suggests that it was placed at the lower part of the slope in his garden. In October 1820 he presented to the readers of Rigstidende his new design for a hygrometer - an instrument to measure air humidity (Esmark, 1820). It was modified from a model developed by John Livingstone, an M.D. from Canton (today Guangzhou), China, published in the Edinburgh Philosophical Journal in 1819 (Livingstone, 1819). The general idea was to put a moisture-absorbing/releasing chemical substance (Livingstone used pure sulfuric acid, which was also used to produce ice) on one side of a balance, balanced against a weight on the other side. The balance was placed under a glass jar open at the bottom to let air freely flow in and out and to protect it from precipitation. Esmark made two new hygrometers according to this model. "Anyone who desires to see these hygrometers can see them at my house." (Enhver, som har Lyst 
dertil, kan see disse Hygrometere hos mig.) (Esmark, 1820). He had tested them for several months and thought they could be used by farmers to predict weather change as a substitute for barometers. He did not, however, use the hygrometer data for his meteorological tables. For the year 1821 he presented more regular monthly data on precipitation in inches - from 1 May through October - apparently the months without frost.

\subsection{The published tables}

Starting on Saturday 24 January 1818, with a table presenting weather data for the first half of the month, the semi-official daily Den Norske Rigstidende published Esmark's meteorological observations, which thus acquired an official air (Fig. 5). It became a regular series, published twice a month - one table for the first half of the month, one for the second half - a total of 24 tables each year, all with the same title, "Meteorologiske Iagttagelser i Christiania [year], anstillede af Prof. Esmark" (Meteorological observations in Christiania [year], made by Prof. Esmark). This series running from 1 January 1818 to 15 December 1838 is absent from all previously published bibliographies of Esmark's works but in fact runs to no less than 503 published tables (Appendix A). These tables present present 7665 days of continuous observations. In addition come the two full years of 1816 and 1817, only published summarily by Esmark (1823) but with the complete record preserved in the original protocols. The whole year 1818 was summed up on 8 January 1819 with, for example, means, and here Esmark also compared the Christiania data to those obtained by Wargentin in Stockholm, by Bugge in Copenhagen, and (no observer given) in St. Petersburg, Russia. It was not a weather forecast but rather a weather "backlog", and this may have dimmed their public interest somewhat. The data given in these published tables differ from the raw data of the protocols by being daily averages. For each day he gave the barometric pressure and temperature, averaged from observations made in the morning, afternoon, and evening (at first without further precision of hour). To calculate these averages he apparently used the formula

$T_{\mathrm{m}}=1 / 4\left(T_{\mathrm{I}}+2 T_{\mathrm{II}}+T_{\mathrm{III}}\right)$,

where $T_{\mathrm{m}}$ is Esmark's daily "mean" temperature, and $T_{\mathrm{I}}, T_{\mathrm{II}}$, and $T_{\mathrm{III}}$ are the observed temperature morning, afternoon and evening, respectively. To the tables, for the second half of each month, he also appended a note with the mean barometric pressure and temperature for the entire month, and indicated which days had the maximum and minimum air pressure and temperature. The mean temperature was given to $1 / 100$ th of a degree (a spurious precision). The series continued in 1820, now also with the daily wind direction. Esmark evidently trusted only himself to calculate the means and set up the tables, and thus the readers of Rigstidende sometimes had to wait for months to read the weather for the last fortnight when he was off on some excursion. From 1834
Esmark's observations were also published in the Christiania newspaper Morgenbladet every day, with two days' delay, i.e. observations for the first day of the month were published on the third, the second on the fifth, etc. This was initiated after Christiania doctors suspected a connection between the weather and the cholera epidemics which struck Norway from 1833 onwards.

\section{Methods}

\subsection{Homogeneity testing}

A homogeneous climatic time series shows variations in climate without being disturbed by other factors involved, like changes in the environment, observational procedures or instrument calibration. For the study of climate variations the use of homogeneous series is of paramount importance, as otherwise the climate analysis may be wrong (e.g. Auer et al., 2007; Moberg and Alexandersson, 1997; Tuomenvirta, 2001). For testing the homogeneity of Esmark's temperature series we selected the standard normal homogeneity test (SNHT) with a significance level of 0.05 , which has been widely used for testing of both precipitation series and temperature series (Alexandersson, 1986; Alexandersson and Moberg, 1997; Ducré-Robitaille et al., 2003). The first version of the test (Alexandersson, 1986) had one step change as the only possibility, whereas in the version of 1997 both double shifts and a trend were possible outcomes of the test. In any year the significance of a potential break is examined. The testing followed the principle of comparing a candidate series (the series under testing) against a reference series. The reference may be series from one or more neighbouring stations. A candidate series may also be observations at one particular time of the day which are compared with other observation times for the same station. In the latter case we call this "internal testing". Contemporary neighbouring series overlapping Esmark's observations are too short to be used in the homogeneity testing. The nearest stations that could have been used are Stockholm or Uppsala, about $350 \mathrm{~km}$ from Oslo. The problem with using series so far away is that spatial temperature variations could be interpreted as inhomogeneities. Therefore, our chosen method is internal testing. Later measurement series from observation stations in the Oslo area may, however, be of some use in some analyses, and these are listed with Esmark's in Table 1 with their national station number (identifier) and name. While the official names of the stations refer to their sites, for convenience we will often refer to the names of the observers in the text, i.e. the column "Additional information" in Table 1. Before the analysis started, all observations in degrees Réaumur were converted into degrees Celcius by multiplying by the factor 1.25 . 


\section{Results}

\subsection{Detection of inhomogeneities}

First, we will use SNHT for detection of the inhomogeneities and will thereafter treat each inhomogeneity in more detail and produce corrections. The testing was performed for both seasonal (Table 2) and monthly (Table 3) resolutions where observations taken in the morning (I), midday (II) and evening (III) were compared with each other. By comparing several test results it was possible to decide at which observation time a shift (inhomogeneity) occurred. Most striking are the huge shifts detected in spring, summer and autumn when the morning observation was involved. The most probable year for the shift was 1827; in particular, this was true for the single-shift test. Here we apply the common convention to define the shift year as the last year before the shift. We have to conclude that the morning observation is inhomogeneous. Further investigation of the daily observations (not shown) suggested that the change took place in the month of March 1828.

When the evening observation was tested against the midday observation, a shift seemed to occur in 1820 or 1821 , most probably in 1821 . However, this break in homogeneity was much less than that of the morning observation (see Table 2). The shift seems to be absent or very weak during winter, so exact dating was impossible. For convenience the end of 1821 was adopted as the time of the inhomogeneity.

Tests including the midday observation revealed no additional shifts than those already detected. The occurrence of the shifts in the tests I vs. II and III vs. II seemed to reflect shifts either in the morning or in the evening observations. For the winter season a shift in the last part of the series was detected; possible shift years were 1832, 1833 or 1834.

The large shift in the morning observation could have masked possible smaller shifts in the series on both sides of this shift. Therefore, the single-shift SNHT was applied on two different parts of Esmark's series: January 1816February 1828 and March 1828-December 1838 (parts 2 and 3 in Table 2). However, no further shifts in the series were detected.

Thus, there are three shifts that seem reliable: one in 1821 for the evening observation, one in 1827 (probably February 1828) for the morning observation and one during winter with possible shift years of 1832,1833 or 1834 . We now proceed to propose corrections.

\subsection{Correcting the shift in 1821.12 in the evening observation}

This inhomogeneity was corrected by using the midday observation that came out of the SNHT as homogeneous. The monthly mean difference between the midday observation and the evening observation on each side of the shift was calculated. Then the evening observation was corrected by adding monthly correction terms so that this mean difference was constant on each side of the shift. It is most common to correct the early part of the series, so this was also done here. Therefore, the period January 1816-December 1821 was corrected, whereas the rest of the series was not. The corrections are given in Table 4.

The corrections are largest in the months where the daily temperature wave is largest, so one could hypothesize that a change in the observation time was the reason for the shift. Strictly speaking, we know Esmark's observation times only in 1833, so this hypothesis is not in contradiction to metadata. However, observation times cannot be the only reason for the shift, because it also appeared in midwinter, when the daily temperature wave is weak. Moreover, the numbers of the corrections are so large that only observation times near midnight would compensate for the low values of the evening observation. Observation times that late seem unlikely. There is some indication that a changed environment could have played a role for this inhomogeneity as Esmark in 1823 planted fruit trees in his garden (see Metadata). A 1-year mismatch of the shift detected by the SNHT is not uncommon.

\subsection{Correcting the shift in 1828.02 in the morning observation}

Esmark (1833) relates that he uses "a night thermometer" for the morning observation. Our hypothesis is that in Esmark's terminology the "night thermometer" was a minimum thermometer. That means that he at some point started to note the night minimum temperature in the column for the morning temperature, rather than the actual morning temperature when he read the barometer. This hypothesis was tested by studying the difference between Esmark's evening observation and the morning observation the following day for the three homogeneous intervals (Table 5; the winter inhomogeneity in the 1830s was ignored). For comparison we used the hourly observations (September 1993-September 2015) at the modern station Oslo - Blindern (18700 Oslo), where the difference between the observation at 21:00 UTC and the minimum temperature for the following night is presented in row 4 in Table 5 . The interval for the night minimum was from 21:00 to 08:00 UTC, i.e. the same observation times as Esmark used at least for his barometric observations in 1833 .

In the earliest time interval (row 1) the differences in Esmark's observations are very much smaller than those from Blindern, so it is impossible that Esmark in this early interval could have recorded the nightly minimum temperature in the column for the morning observation. In the next interval (row 2) the differences are somewhat larger, but far too small compared to Blindern, so the same conclusion has to be drawn: no minimum thermometer was in use. However, in the third interval (row 3) the differences are nearly the same as those for Blindern. Even the monthly variations throughout the year correlate well. We conclude that Esmark for the 
Table 1. Esmark's station at $\emptyset$ vre Vollgate 7 as well as other observation stations used in this article: national station number (identifier) and name, period of observation, station altitude and some additional information. The asterisk before the start year marks the start of hourly observations. $H_{\mathrm{S}}$ is metres above sea level.

\begin{tabular}{llcl}
\hline No. and name & Period (from...to; year, month, day) & $H_{\mathrm{S}}(\mathrm{m})$ & Additional information \\
\hline 18651 Oslo II & $1837.04 .02-1933.12 .31$ & 25 & Astronomical Observatory \\
18654 Oslo - Øvre Vollgate & $1816.01 .01-1838.12 .31$ & 11 & Esmark's observations \\
18655 Oslo - Pilestredet & $1822.10 .19-1827.02 .28$ & 16 & Hansteen's observations \\
18700 Oslo - Blindern & $* 1993.01 .05$ to present & 94 & Main building, MET Norway \\
18815 Oslo - Bygdøy & $* 2012.01 .01$ to present & 15 & Mainly rural station \\
\hline
\end{tabular}

Table 2. The SNHT used for comparison of observations at time $x$ vs. observations at time $y$ ( $x$ vs. $y$ ). The shifts $\left({ }^{\circ} \mathrm{C}\right)$ are given by the last year of each part of the series. For the single-shift test, the corrections needed for the $x$ series to be homogeneous with $y$ series are also given. Corrections should be applied from the start year to the end year of the inhomogeneity (non-significant results are given in italic).

\begin{tabular}{lcrrrrr}
\hline SNHTs & Obs. times & Winter & Spring & Summer & Autumn & Year \\
\hline \multicolumn{7}{l}{ Part $1,1816.01-1838.12:$ the whole length of the series } \\
\hline Single shift & I vs. II & $1833 ;-1.1$ & $1827 ;-2.1$ & $1827 ;-3.3$ & $1824 ;-1.4$ & $1827 ;-1.8$ \\
Single shift & I vs. III & $1832 ;-1.5$ & $1826 ;-2.8$ & $1827 ;-4.0$ & $1827 ;-1.7$ & $1827 ;-2.4$ \\
Single shift & III vs. II & $1821 ; 0.7$ & $1820 ; 1.5$ & $1821 ; 1.3$ & $1821 ; 0.6$ & $1821 ; 0.9$ \\
Double shift & I vs. II & $1826 ; 1834$ & $1818 ; 1827$ & $1817 ; 1827$ & $1824 ; 1829$ & $1823 ; 1827$ \\
Double shift & I vs. III & $1819 ; 1832$ & $1820 ; 1826$ & $1818 ; 1828$ & $1823 ; 1829$ & $1818 ; 1827$ \\
Double shift & III vs. II & $1821 ; 1832$ & $1819 ; 1835$ & $1821 ; 1835$ & $1817 ; 1834$ & $1821 ; 1835$ \\
\hline Part 2, 1816.01-1828.02 & & & & & \\
\hline Single shift & II/I & $1826 ; 0.8$ & $1818 ; 0.7$ & $1817 ; 0.8$ & $1824 ; 1.0$ & $1823 ; 0.5$ \\
Single shift & I/III & $1818 ;-1.0$ & $1820 ;-1.7$ & $1818 ;-1.7$ & $1821 ;-0.9$ & $1818 ;-1.3$ \\
Single shift & III/II & $1821 ;-0.6$ & $1819 ;-1.4$ & $1821 ;-1.2$ & $1817 ;-0.8$ & $1821 ;-0.8$ \\
\hline Part 3, 1828.03-1838.12 & & & & & \\
\hline Single shift & I/II & $1834 ;-1.0$ & $1834 ; 0.4$ & $1830 ;-0.4$ & $1829 ;-0.4$ & $1830 ;-0.5$ \\
Single shift & I/III & $1832 ;-1.3$ & $1836 ;-0.6$ & $1836 ;-0.8$ & $1829 ;-0.9$ & $1836 ;-0.8$ \\
Single shift & III/II & $1833 ; 0.4$ & $1835 ; 0.8$ & $1835 ; 0.9$ & $1834 ; 0.6$ & $1835 ; 0.7$ \\
\hline
\end{tabular}

"morning observation" used a minimum thermometer in the period March 1828-December 1838. Before that he observed temperature in the morning with an ordinary thermometer.

Minimum thermometers were certainly available by 1828 . As early as 1790 , a spirit thermometer with a glass index, very much like what is used up to this day at manual stations, was described to the Royal Society in Edinburgh (Middleton, 1966: p. 152).

If the minimum thermometer was set at the evening observation, the values in the column for morning observation should always be equal to or lower than the evening temperature the previous day. In December this is not true for $26 \%$ of the observations and in June for $6 \%$. These figures reduce to 6 and $2 \%$ in December and June respectively for violations of no more than $1^{\circ} \mathrm{C}$. In practice, different exposure of the two thermometers may violate this test, and one should also take into account the possibility of instrumental errors in Esmark's thermometers. We may conclude that the percentage of violation is not large enough to contradict our con- clusion that a night minimum thermometer was in use. The normal procedure for meteorological institutes when minimum thermometers are introduced is to change the formula for monthly mean calculation. Therefore, the morning temperature will not be corrected. Homogeneity in the monthly means will be obtained by changing formula for monthly mean calculation (see Sect. 4.5).

\subsection{Correcting the shift in the 1830s}

A significant inhomogeneity in winter for the morning observation (in this period identified as minimum temperature) was detected by the SNHT double shift (Table 2 part 1 I vs. II) and also by the single-shift test when the time window was March 1828-December 1838 (Table 2, part 3). A significant shift in spring was also formally detected (Table 2 III vs. II), but with only 3 years on one side of the shift, its significance was considered doubtful. The shift in winter was firstly examined by plotting the morning temperature against the evening temperature, which revealed that there was not 
Table 3. The same as Table 1 but with the single-shift test used at monthly resolution. In the first and third rows the years of the shifts are shown, and in the second and fourth rows the adjustments. Period of observation: January 1816-December 1838.

\begin{tabular}{rrrrrrrrrrrrr}
\hline & Jan & Feb & Mar & Apr & May & Jun & Jul & Aug & Sep & Oct & Nov & Dec \\
\hline I/II & 1834 & 1826 & 1826 & 1830 & 1827 & 1827 & 1827 & 1827 & 1825 & 1827 & 1824 & 1833 \\
& -1.2 & -1.4 & -1.0 & -2.2 & -3.3 & -3.4 & -3.5 & -2.9 & -1.9 & -1.1 & -1.5 & -1.2 \\
III/II & 1828 & 1832 & 1820 & 1819 & 1819 & 1826 & 1821 & 1821 & 1821 & 1820 & 1834 & 1820 \\
& 0.6 & 0.7 & 1.1 & 1.7 & 1.8 & 1.3 & 1.3 & 1.3 & 0.8 & 0.9 & 0.6 & 0.7 \\
\hline
\end{tabular}

Table 4. Corrections $\left({ }^{\circ} \mathrm{C}\right)$ of the evening observation during the period January 1816-February 1821.

\begin{tabular}{cccccccccccc}
\hline Jan & Feb & Mar & Apr & May & Jun & Jul & Aug & Sep & Oct & Nov & Dec \\
\hline 0.6 & 0.6 & 1.0 & 1.2 & 1.3 & 1.2 & 1.3 & 1.3 & 0.9 & 0.8 & 0.3 & 0.5 \\
\hline
\end{tabular}

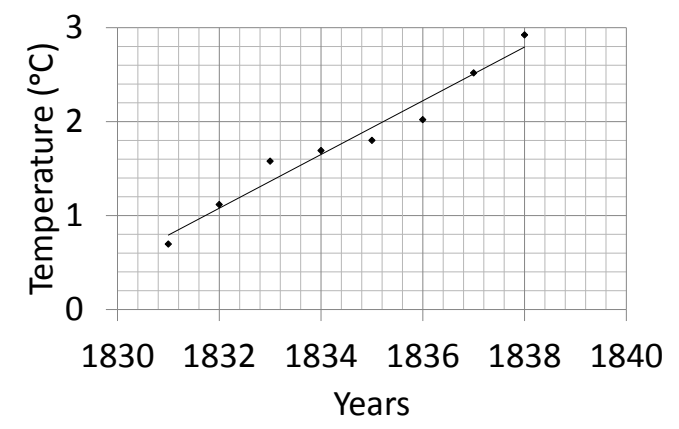

Figure 6. The temperature difference $\left({ }^{\circ} \mathrm{C}\right)$ between Esmark's evening observation and the morning observation the following day for the winter season (December-February) in the period 18311838 .

an abrupt shift in the difference but rather a steady state during 1829-1931 followed by a trend. The graphical plotting was followed by applying the multiple linear regression (MLR) procedure, also known as the Vincent test (Vincent, 1998). The significant inhomogeneity was confirmed, as was the change point year of 1831 . The trend line was found by least-squares regression analysis (Fig. 6). An explanation for the trend may be a change in the observation times. According to Esmark (1833), his observation times were as follows (see Metadata):

- morning: 08:30 ChT = 08:43 CET = 07:43 UTC;

- midday (afternoon): 15:30 ChT $=15: 43 \mathrm{CET}=$ 14:43 UTC;

- evening: $21: 30 \mathrm{ChT}=21: 43 \mathrm{CET}=20: 43 \mathrm{UTC}$.

(ChT: Christiania time, i.e. local time for Christiania (Oslo); CET, Central European Time; UTC, Universal Time Coordinated)

These observation times were for the barometric pressure, but in the afternoon and evening the thermometer was read at the same time as the barometer; however, Esmark does not explicitly say that the morning thermometer was read at the same time as the barometer. He also uses the term "in the later" years, so we do not know from which year these observation times were introduced or whether he also continued to use them in the following years of 1834-1838.

Our hypothesis is that Esmark had another observation time for the temperature observations in the morning than for the pressure observations. Pressure could be observed inside the house, but for the temperature observations he possibly had to leave the house for his garden. Esmark might originally have observed temperature and pressure at the same time in the morning also, but with the introduction of the minimum thermometer he could have thought that the observation time for the morning temperature was not important. In spring, summer and autumn he obviously was right in his thinking as minimum temperature occurs earlier than the morning observation $(08: 30 \mathrm{ChT})$, but in winter the minimum temperature often occurs later in the day as the systematic daily temperature wave is weak. This can explain the changing difference during winter and the stable differences during the other seasons. As Esmark grew older and more frail, he may have got up in the morning later and later. Progressive illness and susceptibility to cold in his later years (Anonymous, 1839) could have made it less convenient to leave the house for the garden in the morning. Following this hypothesis, the minimum temperature was corrected, $\Delta T$, by use of Eq. (2) for the winter season in accordance with the regression line shown in Fig. 6, where $a=$ year (period 18321838). No correction was undertaken for the period 18291831.

$\Delta T=0.2861 \cdot a-523.85$

\subsection{Homogenization of the monthly mean temperature}

Esmark observed only three times a day, so it is far from obvious how monthly mean temperature should be calculated without bias. This problem confronts meteorological institutes worldwide, so formulas for such calculations have been 
Table 5. Difference (Diff, ${ }^{\circ} \mathrm{C}$ ) of median temperature between Esmark's evening observations and the observations the following morning. For comparison the differences between the observation at 21:00 UTC and the minimum temperature the following night are shown for the modern station Oslo - Blindern. The night is defined by the interval 21:00-08:00 UTC. SD $\left({ }^{\circ} \mathrm{C}\right)$ is the standard deviation for the differences.

\begin{tabular}{llrrrrrrrrrrrr}
\hline & & Jan & Feb & Mar & Apr & May & Jun & Jul & Aug & Sep & Oct & Nov & Dec \\
\hline Esmark & Diff & 0.0 & 0.0 & 0.0 & -0.7 & -1.8 & -1.6 & -1.3 & -1.2 & 0.0 & 0.5 & 0.0 & 0.0 \\
1816.01-1821.12 & SD & 3.4 & 2.6 & 2.4 & 2.1 & 2.4 & 2.3 & 2.6 & 2.1 & 2.1 & 2.0 & 2.6 & 2.2 \\
Esmark & Diff & 0.9 & 0.7 & 1.2 & 0.6 & 0.6 & -0.7 & -0.6 & 0.0 & 1.2 & 0.6 & 0.8 & 0.6 \\
$1822.01-1828.02$ & SD & 3.1 & 2.5 & 2.3 & 1.8 & 2.2 & 2.4 & 2.2 & 2.1 & 2.9 & 2.5 & 2.5 & 2.4 \\
Esmark & Diff & 1.3 & 1.5 & 1.9 & 2.2 & 3.1 & 3.1 & 3.1 & 3.1 & 2.5 & 1.9 & 1.6 & 1.3 \\
$1828.03-1838.12$ & SD & 2.6 & 2.3 & 2.5 & 1.8 & 2.1 & 2.2 & 2.4 & 2.3 & 2.2 & 2.1 & 1.9 & 2.7 \\
Blindern & Diff & 1.0 & 1.5 & 2.3 & 2.6 & 3.2 & 3.0 & 2.7 & 2.4 & 2.0 & 1.5 & 1.0 & 1.0 \\
$1993.09-2015.09$ & SD & 1.7 & 1.8 & 1.8 & 1.7 & 1.8 & 1.8 & 1.7 & 1.6 & 1.6 & 1.6 & 1.5 & 1.6 \\
\hline
\end{tabular}



Figure 7. Corrections added to Esmark's series for each season during his period of observation, 1816-1838.

developed (see Appendix C). The formulas contain specific constants valid for each month and site. Strictly speaking, the constants were unknown for Esmark's observation site at Øvre Vollgate, but they are well known for the station 18700 Oslo - Blindern, situated $3.4 \mathrm{~km}$ to the north of Esmark's site. Fortunately, there are indications that the constants for Blindern could also be used for Øvre Vollgate (see Appendix C). Given the constants, the calculation of homogeneous monthly mean temperature was trivial when the homogenized version of the observations at fixed hours was used. We found that the corrections for seasonal means vary from 0.0 to $+0.4^{\circ} \mathrm{C}$ and the annual corrections from 0.0 to $+0.3^{\circ} \mathrm{C}$. How the corrections changed throughout the period of observation is shown in Fig. 7. For the period December 1822-December 1831, no corrections were applied.

\subsection{The Christiania (Oslo) climate in Esmark's period of observation, 1816-1838}

Esmark's observations exhibit a long-term variation pattern characterised by lower values in the start and in the end of the period, whereas the middle of the period was somewhat warmer (see Fig. 8). This is true not only for the annual means but also for all seasons of the year except for winter. For individual years 1822 is warmest except in summer and autumn. The coldest year is 1838 , followed by the years 1816,1829 and 1820.

The year 1816 is of particular interest as it has gone into history as "the year without summer", with an average decrease in global temperatures often ascribed to volcanic activity, resulting in a food shortage in many places in the Northern Hemisphere. However, Esmark's observations show that this summer (JJA) was not extraordinary in Oslo, as the following summers of 1817 and 1821 were approximately $1{ }^{\circ} \mathrm{C}$ colder. The spring temperature in 1816 is, however, the coldest one in the series. The first 3 years of Esmark's series must have been very unfavourable for agriculture due to low temperature. In the grain-growing months (AMJJA) the mean temperature was about $10^{\circ} \mathrm{C}$ for the three consecutive years 1816, 1817 and 1818, i.e. the lowest temperatures in Esmark's series of observation.

\section{Discussion}

\subsection{Overheating of the midday observation?}

The midday observation turned out to be homogeneous, but it may have been overheated by insufficient radiation protection in Esmark's yard or simply the confined space allowing less air flow (wind). This was tested by comparison with the Oslo - Blindern station (18700), which is well protected by a Stevenson screen. Differences between the midday observation and the evening observation exhibit characteristic variations throughout the year, not only for Blindern but also for the Esmark series and the Oslo II series (Astronomical Observatory, 18651) (see station list Table 1 and Fig. 9). Whereas the differences between the Blindern series and Esmark's series were relatively small in the months AugustApril, they are much larger in the months May-July, when the sun is highest in the sky and the radiation reaches its annual maximum. Therefore, one possible interpretation is that Esmark's thermometer was overheated at the midday observation in midsummer, MJJ, by (reflected) shortwave radia- 

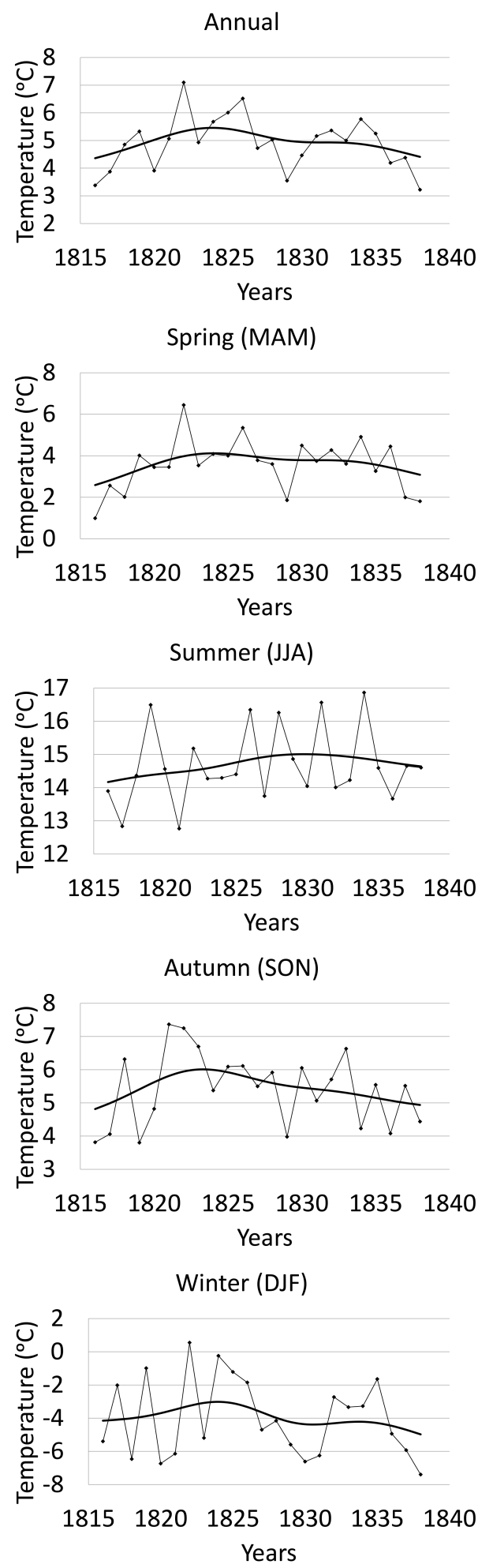

Figure 8. Annual and seasonal means of Esmark's temperature series (symbols) and Gaussian filter (curves) with 3 standard deviations in the Gaussian distribution (e.g. Nordli et al., 2015), corresponding roughly to a 10 -year rectangular filter.

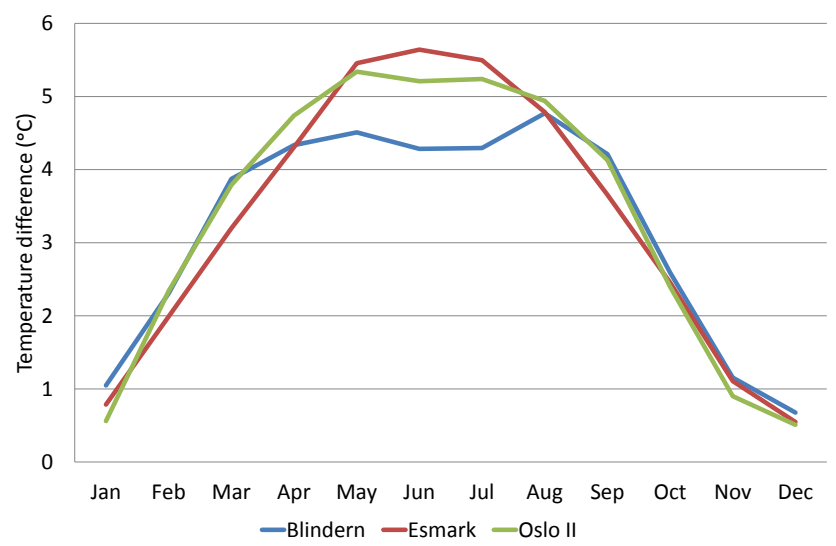

Figure 9. Temperature differences $\left({ }^{\circ} \mathrm{C}\right)$ between the observations at 15:00 and at 21:00 UTC for the following stations: Oslo - Blindern for the period January 1993-September 2015 and Esmark for January $1816-$ December 1838 . The corrections of the evening observations (Table 4) are added to the data for the period January 1816December 1821 before the calculation of the differences and Oslo II (Astronomical Observatory) April 1837-December 1867.

tion. However, when compared to the diurnal pattern at the Oslo II station (Astronomical Observatory), it is seen that the curve representing Esmark's observations quite closely follows the Oslo II curve, also in midsummer (Fig. 9). At the Astronomical Observatory there were three thermometers on different walls - the north, east and west walls (Nordli et al., 2015). At least one of these thermometers was in the shade and therefore available for use at every observation time. This is our main reason for not correcting for a possible overheating of Esmark's midday observation (see also the following Sect. 5.2 and 5.3). The deviation of the Blindern station may be due to this site being more exposed to wind chill and its situation significantly higher above sea level than Esmark's house and the Astronomical Observatory (see Table 1).

The meteorological observations at the Astronomical Observatory started in April 1837 (Nordli et al., 2015), so this series overlaps with Esmark's series by 21 months. The difference of their uncorrected monthly means is shown in Fig. 10. It is evident that for all seasons but winter Esmark's temperatures are somewhat lower than those from the observatory. Esmark died on 26 January 1839 (see Metadata), so the quality of the latest months of his series may possibly be questioned. However, we cannot see any decline in quality directly from his observation protocols. This is also relevant for the discussion of a possible correction of Esmark's midday observation due to overheating. If Esmark's midday observation had been corrected, the discrepancy between Esmark's series and observatory series would have been larger. 


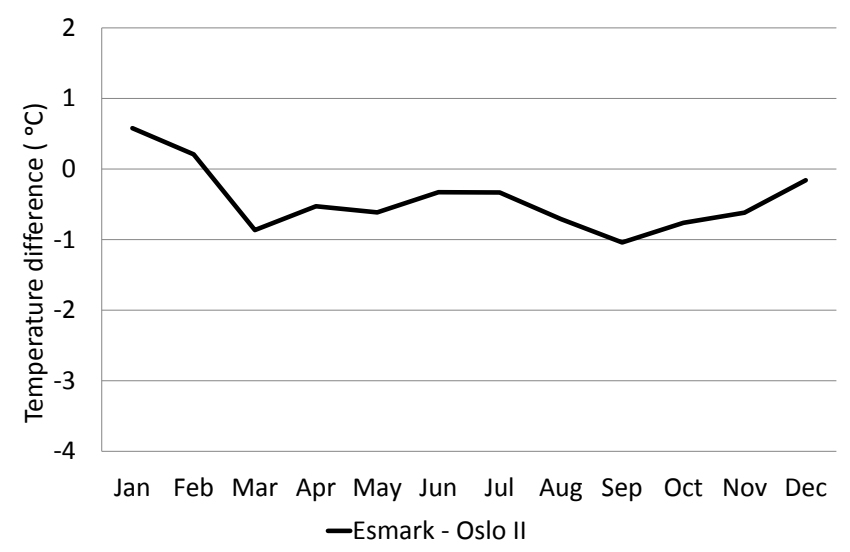

Figure 10. Differences in mean monthly temperature between Esmark's observations at Øvre Vollgate and those at the Astronomical Observatory (Esmark minus observatory) during the period April 1837-December 1838. Temperatures are not corrected.

\subsection{Comparison with Hansteen's observations at the street Pilestredet in Oslo}

During the period November 1822-February 1827 the Christiania professor Christopher Hansteen carried out observations at his home in Pilestredet at the corner of Keysersgate, at the centre of town (Hansteen, 1823, 1824, 1828; Birkeland, 1925: p. 12) (see Table 1 for some further information). The distance from Esmark's site was only about $600 \mathrm{~m}$. Hansteen's observation times varied much but for each month he gives the observation times together with the data (Hansteen, 1824). The distribution of the observation times in UTC is as follows:

$$
\begin{aligned}
& \text { - morning: 06:00, 4\%; 07:00, 44\%; 08:00, 52\%; } \\
& \text { - midday: 13:00, 20\%; 14:00, 78\%; 15:00, 2\%; } \\
& \text { - evening: } 21: 00,6 \% ; 22: 00,88 \% ; 23: 00,6 \%
\end{aligned}
$$

Hansteen's observations were corrected to Esmark's observation times, approximately 08:00, 15:00 and 21:00 UTC by use of the mean daily temperature wave at Blindern, so that Esmark's observations could be compared with the corrected ones of Hansteen (Fig. 11). It is seen that Hansteen's morning observation is much warmer than that of Esmark except during winter. Most likely, the thermometers of Hansteen had been overheated as they were hanging at the southern and northern side of the house (Birkeland, 1925: p. 12). Then it must have been difficult to find shadow in the morning. Also, the midday observation is warmer at Hansteen's site than by Esmark. This is probably due to the fact that Hansteen's garden was protected by the surrounding houses and gardens of the town, which reduced wind, while Esmark's garden was directly exposed to the winds from the adjacent bay. The evening temperatures at Hansteen's house, however, agree well with those from Esmark during summer,

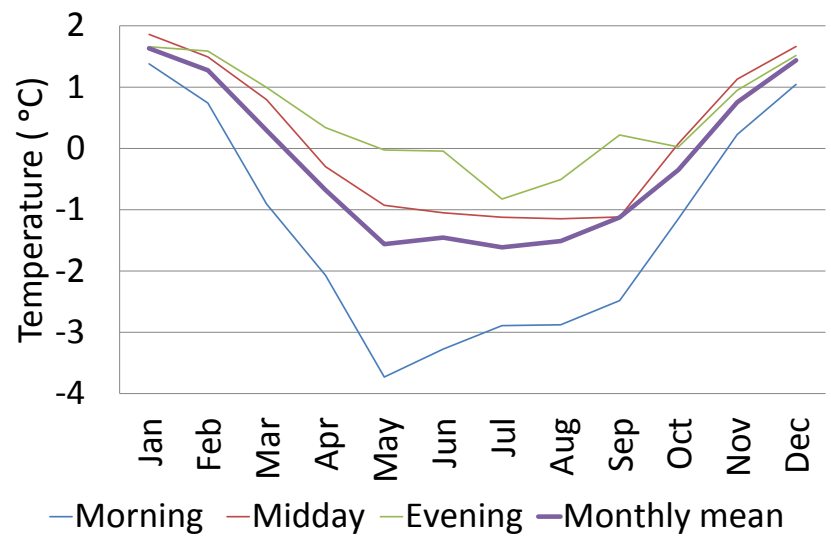

Figure 11. Difference between Esmark's observations at $\emptyset$ vre Vollgate and Hansteen's observations at Pilestredet (Esmark minus Hansteen) during the period November 1822-February 1827 at 08:00, 15:00 and 21:00 UTC.

unlike for the two other observation times. The evening observations occurred after sunset at both sites, whereas the two other observations occurred after sunrise.

Unlike the situation during summer, Hansteen's temperatures are lower than those of Esmark in the period November-March (Fig. 11). In many weather situations the air loses energy by longwave radiation because the shortwave radiation is too small to compensate for the loss. The result is that the coldest air is found at the lowest places in the local terrain, not necessarily at the lowest sites above sea level. Esmark's house lies high in the local terrain at the edge of a slope down to Pipervika (see Metadata), whereas Hansteen's house lies low in the local terrain at a floor of a small valley. The difference in winter temperature is therefore possibly an effect of topography.

\subsection{Comparison with Stockholm and Copenhagen}

The Stockholm and Copenhagen series were not used as reference stations for the homogeneity testing. Their distances from Oslo were considered to be too long, 350 and $450 \mathrm{~km}$ respectively. However, comparison with the Stockholm Observatory and Copenhagen Old Botanical Garden (Closter et al., 2006) with Esmark's observations may provide some indications of the quality of the homogenization (see Fig. 12). Compared to Esmark, Stockholm seems to be relatively warmer in the first four years, 1816-1819, than the rest of the series. Without correction for the years 1816-1821 the differences would have been even larger. Therefore, comparison with Stockholm supports the correction of the series. It is possible that there is another shift in the series in 1819. Some support for this is seen in the homogeneity testing (see Table 2, part 2). However, the may also be due to spatial temperature differences between Stockholm and Oslo, with the long distance between the stations taken into account. 
Table 6. The rank of mean temperature in 1816 for months and seasons during the years 1816-1838 for Oslo (Esmark's observations). For comparison Stockholm is also included. The rank runs from low to high values, so that the lowest temperature is ranked 1.

\begin{tabular}{|c|c|c|c|c|c|c|c|c|c|c|c|c|c|c|c|c|c|}
\hline & Jan & Feb & Mar & Apr & Mar & Jun & Jul & Aug & Sep & Oct & Nov & Dec & Year & Winter & Spring & Summer & Autumn \\
\hline Oslo & 14 & 6 & 1 & 5 & 1 & 7 & 13 & 3 & 2 & 3 & 8 & 11 & 2 & & 1 & 5 & 2 \\
\hline Stockholm & 14 & 3 & 6 & 9 & 1 & 16 & 18 & 9 & 13 & 5 & 8 & 12 & 7 & 6 & 4 & 17 & 3 \\
\hline
\end{tabular}

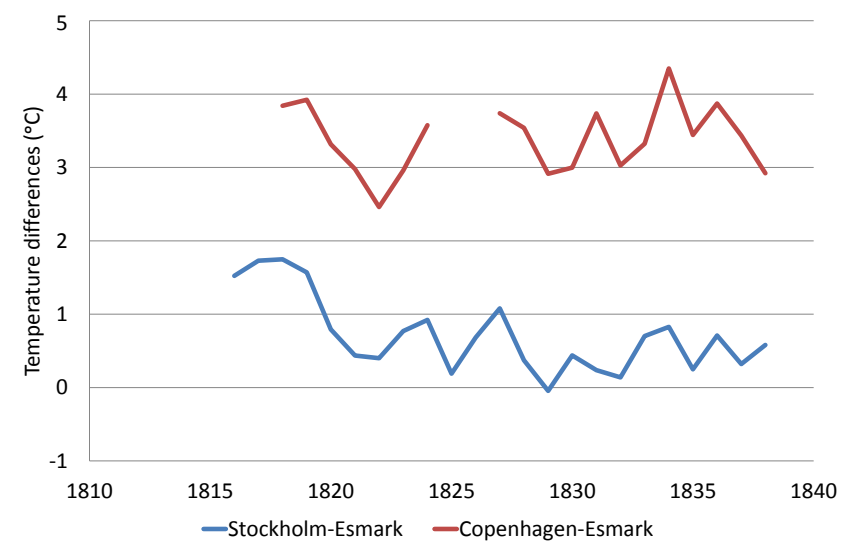

Figure 12. Annual mean temperatures from Stockholm Observatory and Copenhagen old Botanical Garden compared to Esmark's observations at Øvre Vollgate in Oslo.

Furthermore, in spite of homogenization, there may also be small inhomogeneities in the Stockholm series.

Comparison between Copenhagen and Oslo gives no reason for expecting any shift in the series, but 4 years are missing from the Botanical Garden series

\subsection{The summer of 1816 in Christiania (Oslo)}

Several volcanic eruptions affected global climate in the first years of Esmark's period of observation, the Tambora eruption in Asia in 1815 being the largest in terms of sulfur mass ejected and general impact (Stothers 1984; Oppenheimer, 2003). It has given rise to the paradigm for 1816: "the year without a summer". Esmark's observations show, however, that the summer of 1816, though cold, was not extraordinarily cold in Oslo. Moreover, in Stockholm ("Bolin Centre Database", 2016) that summer was rather warm, No. 17 of the 23 summers from 1816 to 1838 , ranked from low to high (Table 6). May, however, was very cold in both cities, and July quite warm in both cities, but in June and August Oslo was much colder relative to the mean value than Stockholm.

Esmark's observations may also be compared to other independent reconstructions of temperature in Norway in the period 1816-1838 (Table 7). One reconstruction for FMA for Austlandet, south-eastern Norway, is based upon ice loss mainly from Lake Randsfjorden (Nordli et al., 2007). Four reconstructions are based upon the first date of grain harvest: Austlandet (Nordli, 2001a); Vestlandet (western Nor- way; Bergen), (Nordli et al., 2003); Lesja (Nordli, 2001b); and Trøndelag (central Norway; Nordli, 2004). The grain harvest date is a proxy for AMJJA temperature in the southern lowland areas, whereas in the mountain valleys (Lesja) and northern areas (Trøndelag) it is a proxy for MJJA temperatures. We also included a gridded multi-proxy series for the nearest grid point to Oslo (Luterbacher et al., 2004). The three reconstructions for Austlandet all have the springsummer of 1816 as the coldest one in the period, whereas in the Esmark series it is listed as No. 3. The reconstructions for the two other regions, Vestlandet (western Norway) and Trøndelag, show a very different picture with relatively warm 1816 summers like the summer in Stockholm based on instrumental observations (Nordli et al., 2003; Nordli, 2004). Vestlandet and Trøndelag belong to other climate regions than Austlandet (Hanssen-Bauer and Førland, 2000), so for a specific summer it may reflect real temperature differences. The very low temperature for spring in 1816 seems to have had a strong influence on agriculture, so the harvest had been delayed in south-eastern Norway. This is reflected in the AMJJA temperature reconstruction. In Fig. 13, proxy and instrumental summer temperatures (JJA) are shown for the whole period of Esmark's observations. The proxy data of Oslo (Luterbacher et al., 2004) agree with the homogenised Esmark's series that the three summers of 1816-1818 were quite cold, not warm like those in Stockholm. The summer of 1819, however, was warm in Oslo (and also in Stockholm) but not in the reconstruction. It is also evident that the variability in the reconstructed series is too small.

The summer temperatures of 1816 have recently been analysed by Luterbacher and Pfister (2015). Their study shows a positive gradient from a cold core of air lying over France with a positive temperature gradient towards eastern and northern Europe, so the paradigm of the severe summer of 1816 has to be modified when it comes to Scandinavia and eastern Europe to take into account significant geographical variation. The authors state that "in eastern Europe, western Russia and parts of eastern Scandinavia, summer temperatures were normal or slightly warmer than average".

\section{Conclusions}

Homogeneity testing (SNHT) of Esmark's temperature observations 1816-1838 in Christiania (Oslo) demonstrated three significant shifts, and we propose corrections for these. First there is a shift in the evening observation in 1821- 
Table 7. The rank of 1816 temperature for seasons during the period 1816-1838 for Oslo (Esmark's observations), and for climate reconstructions from proxy data at different places in Norway. For comparison Stockholm is also included. The rank runs from low to high values, so that the lowest temperature is ranked 1 . The grid point $\left(59.75^{\circ} \mathrm{N}, 10.75^{\circ} \mathrm{E}\right)$ differs only slightly from Esmark's house $\left(59.91^{\circ} \mathrm{N}\right.$, $\left.10.74^{\circ} \mathrm{E}\right)$.

\begin{tabular}{lccccl}
\hline Place, county & Feb-Apr & Apr-Aug & May-Aug & Jun-Aug & References \\
\hline $\begin{array}{l}\text { Oslo, south-eastern Norway } \\
\text { Austlandet, south-eastern Norway }\end{array}$ & 2 & 3 & 3 & 5 & $\begin{array}{l}\text { Esmark's observations } \\
\text { Nordli et al. (2007) } \\
\text { Austlandet, south-eastern Norway }\end{array}$ \\
$\begin{array}{l}\text { Lesja, south-eastern Norway } \\
\text { Bergen, western Norway }\end{array}$ & & 1 & & & $\begin{array}{l}\text { Nordli (2001a) } \\
\text { Nordli (2001b) }\end{array}$ \\
$\begin{array}{l}\text { Trøndelag, central Norway } \\
\text { Stockholm, Sweden } \\
\text { Grid point }\left(59.75^{\circ} \mathrm{N}, 10^{\circ} 75 \mathrm{E}\right)\end{array}$ & 3 & 10 & 1 & & Nordli et al. (2003) \\
\hline
\end{tabular}

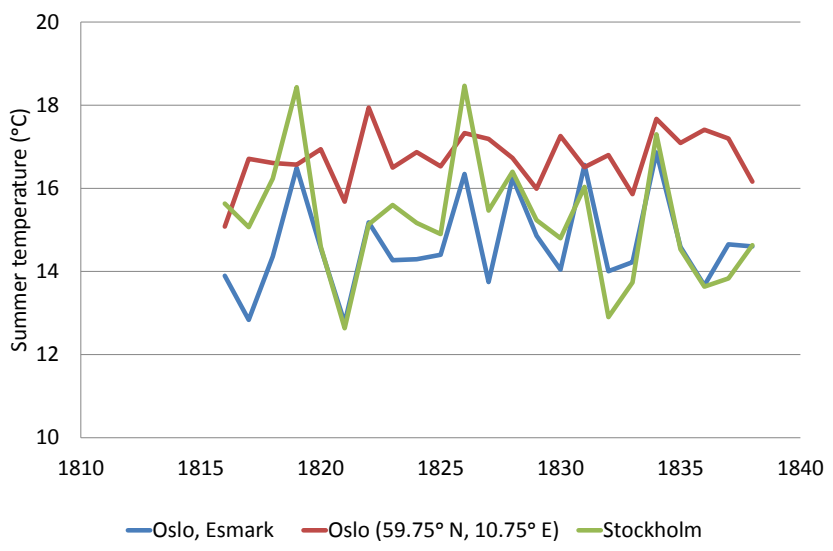

Figure 13. Summer mean temperature (JJA) for Stockholm Observatory, for Øvre Vollgate in Oslo (Esmark's observations), and also for grid point $59.75^{\circ} \mathrm{N}, 10.75^{\circ} \mathrm{E}$ (Oslo) reconstructed by Luterbacher et al. (2004)

1822. Before the shift, the evening observation was corrected by about $+1.3^{\circ}$ for the summer months, but only by about $+0.5^{\circ} \mathrm{C}$ in winter.

A very large shift in the morning temperature was detected in 1827-1828. From Esmark himself we know that he used a "night thermometer" in 1833, identified as a minimum thermometer. This change in instrumentation explains the lower values for the morning observation. During the years 1831 to 1838 the nightly minimum temperature decreased steadily in the winter season - i.e. it was inhomogeneous. The reason seems to be later and later reading of the minimum temperature in the morning. The seasonal corrections of the series are less than $0.5^{\circ} \mathrm{C}$, and for annual means less than $0.4^{\circ} \mathrm{C}$. In the time interval 1822-1831 no corrections are applied. The homogenized temperature series 1816-1838 exhibits low temperature at both ends, with higher temperature in the middle, i.e. in the 1820s. The starting year, 1816, is of particular interest as it has been referred to as "the year without a summer". That summer in Oslo was cold, but not extraordinary cold, as it was only the fifth coldest in the period of observation. However, March and May that year were the coldest ones in the period of Esmark's data, and 1816 and 1838 had the lowest annual means. The first 3 years of Esmark's observation, 1816-1818, were particularly cold in the grain-growing season, April-August, which lends support to the historians' view that these were years of hardship and famine.

\section{Data availability}

The underlying data for this analysis of Esmark's data are stored in the database of the Norwegian Meteorological Institute (www.met.no). The original data are in degrees Réaumur, but transformed to degrees Celcius by multiplying by 1.25 . There are three data sets: (1) sub-daily data, (2) monthly means, and (3) homogenized monthly means, resulting from the corrections described in the present paper. All data sets may be accessed through the national station numerical identifier 18654 or the place name Øvre Vollgate. The program for accessing the data is at present at www.met.no. In the future the program may be changed but there will always be programs available for downloading Norwegian meteorological data from the institute's home page. 
Appendix A: Esmark's meteorological tables in Den Norske Rigstidende

Esmark, J. 1818/19. Meteorologiske Iagttagelser i Christiania 1818, anstillede af J. Esmark. Den Norske Rigstidende 1818, No. 7 (24 January); No. 10 (4 February); No. 14 (18 February); No. 18 (4 March); No. 23 (21 March), No. 28 (8 April), No. 32 (22 April); No. 37 (9 May); No. 40 (20 May), No. 45 (6 June), No. 49 (20 June), No. 54 (8 July); No. 59 (25 July); No. 63 (8 August); No. 67 (21 August); No. 71 (5 September); No. 83, (17 October); No. 84 (21 October), No. 86 (28 October); No. 88 (4 November); No. 95 (28 November); No. 98 (9 December); No. 102 (23 December); No. 3 (8 January 1819).

Esmark, J. 1819/20. Meterologiske Iagttagelser i Christiania 1819, anstillede af J. Esmark. Den Norske Rigstidende No. 6 (19 January); No. 11 (5 February); No. 16 (23 February); No. 19 (5 March); No. 24 (23 March); No. 26 (6 April); No. 33 (23 April); No. 36 (4 May); No. 41 (21 May); No. 48 (15 June); No. 49 (18 June); No. 54 (6 July); No. 62 (3 August); No. 65 (13 August); No. 67 (20 August); No. 78 (28 September); No. 79 (1 October) No. 82 (12 October); No. 84 (19 October); No. 89 (5 November); No. 95 (26 November); No. 99 (10 December); No. 103 (24 December); No. 2 (7 January 1820).

Esmark, J. 1820/21. Meteorologiske Iagttagelser i Christiania 1820, anstillede af J. Esmark. Den Norske Rigstidende, No. 7 (25 January); No. 11 (8 February), No. 14 (18 February); No. 18 (3 March); No. 24 (24 March); No. 28 (7 April); No. 32 (21 April); No. 37 (9 May); No. 41 (23 May); No. 47 (13 June); No. 50 (23 June); No. 54 (7 July); No. 58 (21 July); No. 63 (8 August); No. 68 (25 August); No. 72 (8 September); No. 77 (26 September); No. 81 (10 October); No. 85 (24 October); No. 88 (3 November); No. 94 (24 November); No. 98 (8 December); No. 103 (26 December); No. 3 (9 January 1821$)$.

Esmark, J. 1821/22. Meteorologiske Iagttagelser i Christiania 1821, anstillede af J. Esmark. Den Norske Rigstidende, No. 7 (23 January), står bare snee, men ikke mengde; No. 11 (6 February); No. 16 (23 February); No. 21 (13 March); No. 23 (20 March); No. 29 (10 April); No. 33 (24 April), No. 38 (11 May); No. 41 (22 May); No. 45 (5 June); No. 52 (29 June); No. 55 (10 July); No. 58 (20 July); No. 63 (6 August); No. 68 (24 August); No. 72 (7 September); No. 76 (21 September); No. 80 (5 October); No. 85 (22 October); No. 89 (5 November); No. 93 (19 November)(nytt moderne plusstegn); No. 98 (7 December); No. 102 (21 December); No. 2 (7 January 1822).

Esmark, Jens 1822/23. Meteorologiske Iagttagelser i Christiania 1822, anstillede ved J. Esmark. Den Norske Rigstidende, No. 5 (18 January); No. 10 (4 February); No. 15 (22 February); No. 18 (4 March); No. 23 (22 March); No. 28 (8 April); No. 32 (22 April); No. 36 (6 May); No. 42 (27 May); No. 45 (7 June) not nedbørmåling; No. 50 (24 June); No. 81 (11 October); No. 82 (14 October); No. 83 (18 Oc- tober); No. 84 (21 October); No. 87 (1 November); No. 89 (8November); No. 90 (11 November); No. 92 (18 November); No. 94 (25 November); No. 96 (2 December); No. 98 (9 December); No. 102 (23 December); No. 2 (6 January 1823).

Esmark, J. 1823/24. Meteorologiske Iagttagelser i Christiania 1823, anstillede ved J. Esmark. Den Norske Rigstidende No. 7 (24 January); No. 11 (7 February); No. 15 (21 February); No. 20 (10 March); No. 24 (24 March); No. 27 (4 April); No. 31 (18 April); No. 36 (5 May); No. 40 (19 May); No. 46 (9 June); No. 49 (20 June); No. 75 (19 September); No. 76 (22 September); No. 77 (26 September); No. 78 (29 September); No. 79 (3 October); No. 81 (10 October); No. 82 (13 October); No. 84 (20 October); No. 88 (3 November); No. 93 (21 November); No. 98 (8 December); No. 102 (22 December); No. 2 (5 January 1824).

Esmark, J. 1824/25. Meteorologiske Iagttagelser i Christiania 1824, anstillede ved J. Esmark. Den Norske Rigstidende No. 6 (19 January); No. 11 (5 February); No. 15 (19 February); No. 20 (8 March); No. 24 (22 March); No. 29 (8 April); No. 33 (22 April); No. 37 (6 May); No. 42 (24 May); No. 45 (3 June); No. 50 (21 June); No. 54 (5 July); No. 59 (22 July); No. 64 (9 August); No. 68 (23 August); No. 74 (13 September); No. 77 (23 September); No. 80 (4 October); No. 86 (25 Oktober); No. 89 (4 November); No. 96 (29 November); No. 98 (6 December); No. 103 (23 December); No. 2 (6 Januar 1825).

Esmark, J. 1825/26. Meteorologiske Iagttagelser i Christiania 1825, anstillede ved J. Esmark. Den Norske Rigstidende No. 7 (24 January); No. 11 (7. February), No. 15 (21 February); No. 18 (3. March); No. 24 (24 March); No. 29 (11 April); No. 33 (25 April); No. 36 (5 May); No. 40 (19 May); No. 45 (6 June); No. 49 (20 June); No. 53 (4 July); No. 70 (1 September); No. 71 (5 September); No. 73 (12 September); No. 74 (15. September); No. 76 (22 September); No. 79 (3 October), No. 85 (24 October); No. 89 (7 November); No. 93 (21 November); No. 97 (5 December); No. 102 (22 December); No. 2 (5 January 1826).

Esmark, J. 1826/27. Meteorologiske Iagttagelser i Christiania 1826, anstillede ved J. Esmark. Den Norske Rigstidende No. 8 (26 January); No. 12 (9 February); No. 17 (27 February); No. 19 (6 March); No. 23 (20 March); No. 28 (6 April); No. 33 (24 April); No. 36 (4 May); No. 43 (29 May); No. 45 (5 June); No. 50 (22 June); No. 55 (10 July): No. 58 (20 July); No. 62 (3 August); No. 67 (21 August); No. 72 (7 September); No. 77 (25 September); No. 80 (5 Oktober); No. 84 (19 October); No. 88 (2 November); No. 93 (20 November); No. 97 (4 December); No. 102 (21 December); No. 2 (4 January 1827).

Esmark, J. 1827/28. Meteorologiske Iagttagelser i Christiania 1827, anstillede ved J. Esmark. Den Norske Rigstidende, No. 7 (22 January); No. 11 (5 February); No. 16 (22 February); No. 19 (5 March); No. 24 (22 March); No. 28 (5 April); No. 32 (19 April); No. 37 (7 May); No. 43 (28 May); No. 48 (14 June); No. 50 (21 June); No. 54 (5 July); No. 58 (19 July); No. 79 (1 October); No. 80 (4 October); No. 81 (8 
October); No. 82 (11 October); No. 83 (15 October); No. 84 (18 October); No. 89 (5 November); No. 94 (22 November); No. 97 (3 December); 102 (20 December); No. 2 (7 January 1828 ) - also sums up last 10 years and compares with Stockholm; the coldest years were 1819 and 1820, and the mildest 1822 and 1826.

Esmark, J. 1828/29. Meteorologiske Iagttagelser i Christiania 1828, anstillede ved J. Esmark. Den Norske Rigstidende, No. 6 (21 January); No. 10 (4 February); No. 15 (21 February); No. 18 (3 March); No. 24 (24 March); No. 27 (3 April - mange solpletter); No. 32 (21 April); No. 36 (5 May); No. 40 (19 May); No. 45 (5 June); No. 49 (19 June); No. 53 (3 July); No. 59 (24 July); No. 63 (7 August); No. 78 (29 September); No. 79 (2 October); No. 81 (9 October); No. 84 (20 October); No. 88 (3 November); No. 94 (24 November); No. 98 (8 December); No. 102 (22 December); No. 2 (5 January 1829).

Esmark, J. 1829/30. Meteorologiske Iagttagelser i Christiania 1829, anstillede ved J. Esmark. Den Norske Rigstidende, No. 8 (26 January); No. 11 (5 February); No. 15 (19 February); No. 19 (5 March - den strengeste vinter på mange år); No. 24 (23 March); No. 27 (2 April); No. 33 (23 April); No. 37 (7 May); No. 42 (25 May); No. 46 (8 June); No. 50 (22 June); No. 54 (6 July); No. 78 (28 September); No. 79 (30 September); No. 80 (5 October); No. 81 (8 October); No. 85 (22 October); No. 87 (29 October); No. 89 (5 November); No. 90 (9 November); No. 94 (23 November); No. 99 (10 December); No. 103 (24 December); No. 2 (7 January 1830).

Esmark, J. 1830/31. Meteorologiske Iagttagelser i Christiania 1830, anstillede ved J. Esmark. Den Norske Rigstidende, No. 7 (25 January); No. 11 (8 February); No. 14 (18 February); No. 18 (4 March); No. 22 (18 March); No. 27 (5 April); No. 31 (19 April); No. 36 (6 May); No. 40 (19 May); No. 46 (9 June); No. 50 (23 June); No. 53 (5 July); No. 57 (19 July); No. 63 (9 August); No. 70 (1 September); No. 73 (13 September); No. 78 (29 September); No. 81 (11 October); No. 84 (21 October); No. 91 (15 November); No. 95 (29 November); 98 (9 December); No. 102 (23 December); No. 3 (10 January 1831).

Esmark, J. 1831/32. Meteorologiske Iagttagelser i Christiania 1831, anstillede ved J. Esmark. Den Norske Rigstidende, No. 10 (3 February); No. 11 (7 February); No. 17 (28 February); No. 20 (10 March); No. 25 (28 March); No. 28 (7 April); No. 33 (25 April); No. 39 (12 May); No. 43 (22 May); No. 52 (12 June); No. 57 (23 June); No. 63 (7 July); No. 70 (24 July); No. 75 (4 August); No. 85 (28 August); No. 88 (4 September); No. 97 (25 September); No. 102 (10 October); No. 110 (3 November); No. 112 (10 November); No. 118 (1 December); No. 119 (4 December); No. 1 (1 January 1832); No. 2 (5 January 1832).

Esmark, J. 1832/33. Meteorologiske Iagttagelser i Christiania 1832, anstillede ved J. Esmark. Den Norske Rigstidende, No. 10 (2 February); No. 11 (5 February); No. 19 (4 March); No. 20 (8 March); No. 26 (26 March); No. 30 (12 April); No. 33 (22 April); No. 37 (6 May); No. 43 (20 May);
No. 52 (10 Juni); No. 57 (21 Juni); No. 63 (5 July); No. 70 (22 July); No. 78 (9 August); No. 86 (28 August - usedvanlig kold sommer); No. 92 (11 September); No. 98 (25 September); No. 103 (7 October); No. 108 (25 October); No. 111 (4 November); No. 117 (25 November); No. 122 (13 December); No. 127 (30 December); No. 4 (13 January 1833).

Esmark, J. 1833/34. Meteorologiske Iagttagelser i Christiania 1833, anstillede ved J. Esmark. Den Norske Rigstidende, No. 10 (3 February); No. 12 (10 February); No. 18 (3 March); No. 24 (24 March); No. 25 (28 March); No. 30 (14 April); No. 35 (2 May); No. 37 (9 May); No. 44 (26 May); No. 50 (9 June); No. 58 (27 June); No. 63 (9 July); No. 77 (11 August); No. 80 (18 August); No. 86 (1 September); No. 91 (12 September); No. 97 (26 September); No. 103 (13 October); No. 105 (20 October); No. 110 (7 November); No. 115 (24 November); No. 120 (12 December); No. 123 (22 December); No. 2 (5 January 1834).

Esmark, J. 1834/35. Meteorologiske Iagttagelser i Christiania 1834, anstillede ved J. Esmark. Den Norske Rigstidende, No. 7 (23 January); No. 10 (2 February); No. 16 (23 February); No. 18 (2 March); No. 24 (23 March); No. 27 (3 April); No. 32 (20 April); No. 37 (4 May); No. 43 (18 May); No. 53 (10 June); No. 60 (26 June); No. 68 (15 July)(regnet som falt på en kvadratfods flate utgjorde 4 rhinlandskae tommer eller 576 kubikktommer); No. 71 (22 July); No. 79 (10 August), No. 83 (19 August); No. 90 (7 September); No. 96 (21 September); No. 102 (5 October); No. 107 (23 October); No. 111 (6 November); No. 117 (27 November); No. 119 (4 December); No. 126 (28 December); No. 2 (8 January 1835).

Esmark, J. 1835/36. Meteorologiske Iagttagelser i Christiania 1835, anstillede ved J. Esmark. Den Norske Rigstidende, No. 10 (1 February); No. 12 (8 February); No. 15 (19 February); No. 20 (8 March); No. 24 (22 March); No. 28 (5 April); No. 34 (26 April); No. 40 (10 May); No. 50 (2 June); No. 54 (11 June); No. 58 (21 June); No. 65 (7 July); No. 72 (23 July); No. 79 (9 August); No. 88 (30 August); No. 91 (6 September); No. 99 (24 September); No. 105 (11 October); No. 107 (18 October); No. 112 (5 November); No. 118 (26 November); No. 120 (3 December); No. 126 (24 December); No. 3 (10 January 1836).

Esmark, J. 1836/37. Meteorologiske Iagttagelser i Christiania 1836, anstillede ved J. Esmark. Den Norske Rigstidende, No. 7 (24 January); No. 15 (21 February); No. 17 (28 February); No. 19 (6 March); No. 23 (20 March); No. 27 (3 April); No. 32 (21 April); No. 38 (5 May); No. 45 (22 May); No. 50 (2 June); No. 59 (23 June); No. 66 (10 July); No. 70 (19 July); No. 78 (7 August); No. 85 (23 August?); No. 92 (8 September); No. 98 (22 September); No. 105 (9 October); No. 111 (30 October); No. 112 (3 November); No. 119 (27 November); No. 125 (18 December); No. 126 (22 December); No. 3 (5 January 1837).

Esmark, J. 1837/38. Meteorologiske Iagttagelser i Christiania 1837, anstillede ved J. Esmark. Den Norske Rigstidende, No. 10 (22 January); No. 17 (7 February); No. 22 (19 February); No. 22 (2 March); No. 34 (19 March); No. 41 (4 
April); No. 48 (20 April); No. 53 (2 May); No. 61 (21 May); No. 67 (4 June); No. 74 (20 June); No. 82 (9 July); No. 86 (18 July); No. 93 (3 August); No. 100 (20 August); No. 106 (3 September); No. 113 (19 September); No. 120 (5 October); No. 126 (19 October); No. 132 (2 November); No. 139 (19 November); No. 145 (3 December); No. 152 (19 December); No. 2 (4 January 1838).

Esmark, J. 1838. Meteorologiske Iagttagelser i Christiania 1838, anstillede ved J. Esmark. Den Norske Rigstidende, No. 10 (18 January); No. 19 (3 February); No. 29 (20 February); No. 36 (4 March); No. 45 (20 March); No. 53 (3 April); No. 62 (19 April); No. 70 (3 May); No. 79 (19 May); No. 87 (2 June); No. 98 (19 June); No. 108 (4 Junly); No. 117 (19 July); No. 127 (2 August); No. 137 (19 August); No. 148 (6 September); No. 156 (20 September); No. 164 (4 October); No. 173 (20 October); No. 181 (3 November); No. 190 (18 November); No. 199 (4 December); No. 207 (18 December).

\section{Appendix B: Corrections of Esmark's thermometer?}

The corrections are very small for the frequent winter temperatures but as high as $0.5^{\circ} \mathrm{C}$ for frequent summer temperatures. Due to the uncertainty with the identification of Esmark's thermometer, we have not applied these corrections to his observations. It should also be kept in mind that Esmark used another thermometer, i.e. a minimum thermometer for the period March 1828-December 1838, which may also have instrumental corrections. However, he was a skilled instrument builder, so it is not likely that he used a thermometer with larger corrections that those in Table B1.

\section{Appendix C}

Table C1. Formulas for calculation of monthly mean temperature, $T$, where $T_{08}, T_{15}$, and $T_{21}$ are monthly means at observation times 08:00, 15:00 and 21:00 UTC respectively; $T_{\mathrm{n}}$ is monthly mean night temperature; and $k_{g}$ and $k_{f}$ are constants. Mohn's formula is also often called the $C$ formula.

\begin{tabular}{lll}
\hline Mohn's formula & $T=T_{c}+C$ & $T_{c}=\frac{T_{08}+T_{15}+T_{21}}{3}$ \\
Köppen's formula & $T=T_{f}-k\left(T_{f}-T_{\mathrm{n}}\right)$ & $T_{f}=\frac{T_{15}+T_{21}}{2}$ \\
\hline
\end{tabular}

MET Norway calculates monthly mean temperatures for manual stations by Mohn's (also called the $C$ formula) and Köppen's formulas (Birkeland, 1936; Gjelten et al., 2014; Nordli et al., 2015), so we also chose to use those formulas for Esmark's observations: the monthly mean temperature, $T$, may be calculated by Mohn's formula and a modified Köppen's formula (Table C1).

A "true" monthly mean temperature, $T$, may be calculated by the arithmetic mean of hourly observation according to definition, so for a station that has hourly observations the constants, $C$ and $k_{f}$, are easily calculated by rearranging Mohn's and Köppen's formulas. For Esmark's series from $\emptyset$ vre Vollgate the constants were unknown. It was assumed that the constants from Blindern could also be used for $\emptyset_{v r e}$ Vollgate. An indication of the robustness of this assumption was tested by comparison with a short series of hourly observations from the station 18815 Oslo - Bygdøy (15 m a.s.l.). The test procedure started with calculation of the constants for the Blindern series based on the period December 2012September 2015. These constants were then used for the calculation of mean monthly temperatures for Bygdøy for the same period, which were compared with the "true" monthly means, i.e. those calculated using the hourly observations. For Mohn's formula the deviation from the true means varied from $-0.06^{\circ} \mathrm{C}$ in December to $+0.31{ }^{\circ} \mathrm{C}$ in September, giving $+0.10^{\circ} \mathrm{C}$ for the whole year. For seven of the months the deviation from the true value was less than $\pm 0.1^{\circ} \mathrm{C}$. Corresponding figures for Köppen's formula were $-0.06^{\circ} \mathrm{C}$ in July, $+0.16^{\circ} \mathrm{C}$ in September and $+0.01^{\circ} \mathrm{C}$ for the whole year.

Table B1. Instrument correction (Corr.) for thermometer readings (Temp.). The thermometer may have been used by Esmark between 1816 and 1838 .

\begin{tabular}{lrrrrrrrrr}
\hline Temp. $\left({ }^{\circ} \mathrm{C}\right)$ & 25.00 & 18.75 & 12.50 & 6.25 & 0.00 & -6.25 & -12.50 & -18.75 & -25.00 \\
Corr. $\left({ }^{\circ} \mathrm{C}\right)$ & +0.50 & +0.50 & +0.38 & +0.38 & +0.13 & +0.13 & +0.13 & +0.13 & +0.63 \\
\hline
\end{tabular}


Edited by: S. Bronnimann

Reviewed by: R. Przybylak and two anonymous referees

\section{References}

Alexandersson, H.: A homogeneity test applied to precipitation data, J. Climatol., 6, 661-675, doi:10.1002/joc.3370060607, 1986.

Alexandersson, H. and Moberg, A.: Homogenization of Swedish Temperature Data. Part I: Homogeneity Test for Linear Trends, Int. J. Climatol., 17, 25-34, doi:10.1002/(SICI)10970088(199701)17:1<25::AID-JOC103>3.0.CO;2-J, 1997.

Andersen, B. G.: Jens Esmark - a pioneer in glacial geology, Boreas, 21, 97-102, 1992.

Anonymous: Biografi öfver Jens Esmark, Professor i Bergvetenskapen vid Universitetet i Christiania, Riddar af Kongl, WasaOrden. Kgl. [svenska] Vetenskaps-Akademien, Nya Handlingar 1838, 312-323, written by: Esmark's son Hans Morten Thrane Esmark \& Jøns Jacob Berzelius, 1839.

Auer, I., Böhm, R., Jurkovic, A., Lipa, W., Orlik, A., Potzmann, R., Schöner, W., Ungersböck, M., Matulla, C., Briffa, K., Jones, P., Efthymiadis, D., Brunetti, M., Nanni, T., Maugeri, M., Mercalli, L., Mestre, O., Moisselin, J.-M., Begert, M., MüllerWestermeier, G., Kveton, V., Bochnicek, O., Stastny, P., Lapin, M., Szalai, S., Szentimrey, T., Cegnar, T., Dolinar, M., GajicCapka, M., Zaninovic, K., Majstorovic, Z., and Nieplova, E.: HISTALP - historical instrumental climatological surface time series of the Greater Alpine Region, Int. J. Climatol., 27, 17-46, doi:10.1002/joc.1377, 2007.

Berger, A.: A Brief History of the Astronomical Theories of Paleoclimates, in: Climate Change, edited by: Berger, A., Springer Verlag, Wien, doi:10.1007/978-3-7091-0973-1_8, 107129, 2012.

Bergström, H. and Moberg, A.: Daily Air Temperature and Pressure Series for Uppsala (1722-1998), Climatic Change, 53, 213-252, doi:10.1023/A:1014983229213, 2002.

Birkeland, B. J.: Ältere Meteorologische Beobachtungen in Oslo (Kristiania). Luftdruck und Temperatur in 100 Jahren, Old meteorological observations in Oslo, One hundred years of air pressure and temperature, submitted 1923, Geofys. Publ. III, 56 pp., 1925.

Birkeland, B. J.: Mittel und Extreme der Lufttemperatur, Geofys. Publ. XIV., Oslo, 1936.

Bolin Centre Database: WWW Document, http://bolin.su.se/data/ stockholm/homogenized_monthly_mean_temperatures.php, last access: 2 October 2016.

Closter, A. M., Closter, R. M., Cappelen, J., Christensen, J. H., Christoffersen, K., and Kern-Hansen, C.: Temperature measurements in Copenhagen from 1767 to 1860, Technical report No. 06-13, Danish Meteorological Institute, available at: http: //www.dmi.dk (last access: 9 February 2016), 2006

Document 1: Riksarkivet (National Archive), Oslo, Christiania Byfogden A Tinglysning, Tinglysninger frem til 1819, property No. 308, Sold to JE 19 August 1815.

Document 2: Riksarkivet (National Archive), Oslo, B VII 1 Kristiania Magistrat Fa - Folketellinger 0001 (1815); Ga - Manntall 0004 (1816), 0005 (1826, 1828), 0006 (1829, 1830), 0007 (1831, 1833), 0008 (1834), 0009 (1835, 1836), 0010 (1837); Kristiania Magistrat skatter Gc.
Document 3: Oslo Byarkiv (Oslo City Archive), Christiania matrikuleringsprotokoll, 1830, Document available as PDF at Oslo Kommune (Oslo municipality), Plan og bygningsetaten, p. 142.

Document 4: Oslo Kommune (Oslo municipality), Plan og bygningsetaten, 1938, Journal No. 1768/1938 Riving av (demolition of) Øvre Vollgt, 7, Document copy available on fiche.

Document 5: Oslo Byarkiv (Oslo City Archive), Christiania matrikuleringsprotokoll, 1830, Documents available as PDF at Oslo Kommune (Oslo municipality), Plan og bygningsetaten, p. 141, p. 142 , p. 143 and p. 163.

Document 6: Landarkivet (County Archive), Fyn, Denmark, Stamhuset Hofmansgaves Arkiv, J. Esmark, letter to Nils Hofman Bang 31 October 1823.

Ducré-Robitaille, J.-F., Vincent, L. A., and Boulet, G.: Comparison of techniques for detection of discontinuities in temperature series, Int. J. Climatol., 23, 1087-1101, doi:10.1002/joc.924, 2003.

Esmark, J.: Esmark's handwritten observation protocols from Kongsberg. 11 volumes (1802 missing), Riksarkivet (National Archive), Oslo, S-1570, Det norske meteorologiske institutt, F/Fa, Materiale etter professorer, L0001, Esmark's Kongsberg protocols, 1799-1810.

Esmark, J.: Auszug aus einem Schreiben des OberbergamtsAssessor J. Esmarck zu Kongsberg über die Schnee- und Vegetations-linie in Norwegen, Nordisches Archiv für Naturund Artzneywissenschaft und Chirurgie III (3), 197-200, Copenhagen, 1802.

Esmark, J.: Bemærkninger, gjorte paa en Reise til Gousta-Fjeldet i Øvre-Tellemarken, Dated Kongsberg 29 December 1810, Topographisk-Statistiske Samlinger, Udgivne af Det Kongelige Selskab for Norges Vel. Første Deels Andet Bind. Christiania. W. Wulfsberg, 175-196, 1812.

Esmark, J.: Esmark's original handwritten observation protocols from Christiania, 23 volumes, Riksarkivet (National archives), Oslo, S-1570, Det norske meteorologiske institutt, F/Fa, Materiale etter professorer, L0002, Esmark's Christiania protocols, 1816-1838.

Esmark, J.: Et nyt Hygrometer, Den Norske Rigstidende, No. 84, 20 October 1820 .

Esmark, J.: Middel-Barometerstand og Middel-Temperatur for Christiania i de syv Aar fra 1816 til 1822, Magazin for Naturvidenskaberne, Förste Aargangs förste Bind, 1, p. 178, 1823.

Esmark, J.: Bidrag til vor Jordklodes Historie, Magazin for Naturvidenskaberne, Anden Aargangs förste Bind, Förste Hefte, 3, 28 49, 1824.

Esmark, J.: Handwritten eight-page vitae/autobiography, Christiania 15 October 1825, Kungliga Vetenskapsakademien - Royal Swedish Academy of Science, Stockholm, Center for the History of Science, Archives, category "Inkommande skrivelser från personer utan eget arkiv", 1825.

Esmark, J.: Remarks tending to explain the Geological History of the Earth, The Edinburgh New Philosophical Journal, 2, 107121, 1826.

Esmark, J.: Thermometer- og Barometer-Stand i Christiania efter 16325 Observationer i 15 år, Eyr: et medicinsk Tidsskrift, 8, 235239, 1833.

Gjelten, H. M., Nordli, Ø., Grimenes, A. A., and Lundstad, E.: The Ås Temperature Series in Southern Norway-Homogeneity Testing And Climate Analysis, Bull. Geogr. Phys. Geogr. Ser., 7, 726, doi:10.2478/bgeo-2014-0001, 2014. 
Hanssen-Bauer, I. and Førland, E.: Temperature and precipitation variations in Norway 1900-1994 and their links to atmospheric circulation, Int. J. Climatol., 20, 1693-1708, 2000.

Hansteen, C.: Meteorologisk Dagbog for den sidste Fjerdedeel af 1822. Magazin for Naturvidenskaberne, Förste Aargangs förste Bind, 1. Hefte, p. 177, 1823.

Hansteen, C.: Forelöbige Resultater af Barometer-Iagttagelser i Christiania. Magazin for Naturvidenskaberne, Anden Aargangs 2 Hefte, 4, 269-298, 1824.

Hansteen, C.: Timevise Thermometer- og Barometer-Iagttagelser i Trondhjem, Magazin for Naturvidenskaberne, 8, 173, 1828.

Hestmark, G.: Her ligger Sneen evig, Da Dovre falt - for Esmarks barometer, Hist. Tidsskr., 88, 231-249, 2009.

Kratzenstein, C. G.: Forelæsninger over Experimental-Physiken, Kiöbenhavn, Trygt hos Johan Frederik Schultz, Hos Faber og Nitsche, 1791.

Krüger, T.: Discovering the Ice Ages: International Reception and Consequences for a Historical Understanding of Climate, History and Medicine Library 37, Leiden, Brill, 2013.

Luterbacher, J. and Pfister, C.: The year without a summer, Nat. Geosci., 8, 246-248, 2015.

Luterbacher, J., Dietrich, D., Xoplaki, E., Grosjean, M., and Wanner, H.: European seasonal and annual temperature variability, trends and extremes since 1500, https://crudata.uea.ac.uk/cru/ projects/soap/data/recon/, Science, 303, 1499-1503, 2004.

Livingstone, J.: Account of an improved Hygrometer, The Edinburgh Philosophical Journal, 1, 116-117, 1819.

Middleton, W. E. K.: A History of the Thermometer and Its Uses In Meteorology, Johns Hopkins Press, Baltimore, 1966.

Moberg, A. and Alexandersson, H.: Homogenization of Swedish Temperature Data. Part II: Homogenized Gridded Air Temperature Compared with a Subset of Global Gridded Air Temperature Since 1861, Int. J. Climatol., 17, 35-54, 1997.

Moberg, A., Bergström, H., Krigsman, J. R., and Svanered, O.: Daily air temperature and pressure series for Stockholm (17561998), Climatic Change, 53, 171-212, 2002.

Myhre, J. E.: Oslo Bys Historie, Vol. 3, Hovedstaden Christiania, Fra 1814 til 1900, Oslo, 1990.

Nordli, Ø., Lundestad, E., and Ogilvie, A. E.: J. A Late Winter Early Spring Temperature Reconstruction for Southeastern Norway from 1758 to 2008, Ann. Glaciol., 46, 440-408, 2007.

Nordli, $\varnothing$.: Spring and summer temperatures in south eastern Norway (1749-2000), DNMI-klima No. 01/2001, 2001a.

Nordli, Ø.: Reconstruction of Nineteenth Century Summer Temperatures in Norway by Proxy Data from Farmers' Diaries, Climatic Change, 48, 201-218, 2001b.
Nordli, Ø.: Spring and summer temperatures in Trøndelag 17012003, met.no/report No. 05/2004, Meteorological Institute, Oslo, 2004.

Nordli, Ø., Lie, Ø., Nesje, A., and Dahl, S. O.: Spring-summer temperature reconstruction in western Norway 1734-2003: a data-synthesis approach, Int. J. Climatol., 23, 1821-1841, doi:10.1002/joc.980, 2003.

Nordli, Ø., Hestmark, G., Benestad, R. E., and Isaksen, K.: The Oslo temperature series 1837-2012: homogeneity testing and temperature analysis, Int. J. Climatol., 35, 3486-3504, doi:10.1002/joc.4223, 2015.

Oppenheimer, C.: Climatic, environmental and human consequences of the largest known historic eruption: Tambora volcano (Indonesia) 1815, Prog. Phys. Geog., 27, 230-259, 2003.

Rudwick, M. J. S.: Worlds Before Adam. The Reconstruction of Geohistory in the Age of Reform, The University of Chicago Press, Chicago \& London, 2008.

Snorrason, E.: Kratzenstein, C. G. professor physices experimentalis Petropol. et Havn. and his Studies on electricity during the eighteenth century, Acta historica scientiarum naturalium et medicinalium, no. 29, edidit Bibliotheca Universitatis Hauniensis, Odense University Press, Odense, 1974.

Splinter, S.: Zwischen Nützlichkeit und Nachahmung, Eine Biografie des Gelehrten Christian Gottlieb Kratzenstein (17231795), Frankfurt (Main), 2007.

Stothers, R. B.: The Great Tambora Eruption in 1815 and Its Aftermath, Science, 224, 1191-1198, doi:10.1126/science.224.4654.1191, 1984.

Tuomenvirta, H.: Homogeneity adjustments of temperature and precipitation series-Finnish and Nordic data, Int. J. Climatol., 21, 495-506, doi:10.1002/joc.616, 2001.

Vincent, L. A.: A technique for the identification of inhomogeneities in Canadian temperature series, J. Climate, 11, 1094-1104, doi:10.1175/15200442(1998)011<1094:ATFTIO>2.0.CO;2, 1998.

Willaume-Jantzen, V.: Meteorologiske Observationer i Kjøbenhavn, Résumé des Observations Météorologiques de Copenhague, Det Danske Meteorologiske Institut, Kjøbenhavn, i commission hos universitets-boghandler, 1896.

Worsley, P.: Jens Esmark, Vassryggen and early glacial theory in Britain, Mercian Geologist, 16, 161-172, 2006. 